Chapter 14 in The Sage Handbook of Social Psychology, Edited by Michael A. Hogg \& Joel Cooper. Thousand Oaks, CA: Sage Publications, Inc., 2003.

In creating this electronic reprint, we have attempted to keep the style, pagination, and format as close to the published form as possible. Nonetheless, some errors may have occurred. If you discover a substantial error, please contact Craig Anderson using the following email address: caa@iastate.edu.

Please note that this electronic reprint is provided as a courtesy. Please do not post or distribute this reprint in any fashion that may violate the copyright of the original publisher or the authors. Thank you for your interest in this work.

\title{
Human Aggression: A Social-Cognitive View
}

\section{CRAIG A. ANDERSON and L. ROWELL HUESMANN}

Aggressive and violent behavior by one human being toward another is not a new phenomenon. It was prevalent among our hunter/gatherer ancestors 25,000 years ago, among the Greek, Egyptian, and Roman societies two to three thousand years ago, among most societies in the last two centuries, and in almost every society today. Periodically, events such as the Holocaust, the Columbine, Colorado school shootings; or the terrorist attack on the World Trade Center on September 11, 2001 make people wonder 'what the world is coming to'; but although technology has made mass violence easier to accomplish, it is doubtful that people are more prone to be violent today than thousands of years ago. In fact, the portion of the world's population who behave violently today is probably lower than in most previous times. Nevertheless, the prevalence of aggressive and violent behavior today is sufficient to make it a social problem worthy of attention around the world.

\section{RECENT TRENDS}

\section{Frequency of violence}

Measuring societal rates of violence is fraught with difficulties because politics affects definitions and reporting of violence and crime. Homicide rates are usually considered the best measure of societal violence because they are the hardest to distort or hide. Historically, rates of serious interpersonal violence within societies rise and fall over short periods as a function of socioeconomic, demographic, and other factors. For example, the last 100 years of homicide rates in the United States are shown in Figure 14.1 (US Department of Justice, 2001). Rates were highest during the depression and in the 1980s and early 1990s, and have declined substantially in recent years. Nevertheless, 6.5 homicides per 100,000 people is a serious social problem. Furthermore, though the overal homicide rate has dropped significantly since 1994 (due largely to decreased gun homicides), the assault rate among American youth has steadily remained at unacceptably high levels (Surgeon General, 2001).

\section{Cross-national comparisons}

Figure 14.2 displays the 1995 homicide rates for a variety of countries and regions (Maguire and Pastore, 2001). As has been true for most of the last 50 years, the United States has less violence than less developed countries undergoing radical socioeconomic changes, but more homicides than most stable developed countries. However, the picture changes if one considers other measures of violent behavior. Victimization surveys, in which randomly selected representative samples of the population are interviewed, are better measures of nonhomicide types of violence. Rates of aggression and violence reported in victimization surveys are higher than 'officially reported rates' because the political and personal filters are removed from the reporting. For example, in 1991, there were 732 violent crimes per 100,000 population in the United States according to the FBI's Uniform Crime Reports but 2,415 


\section{(Homicides/100,000, NYT, 1996)}

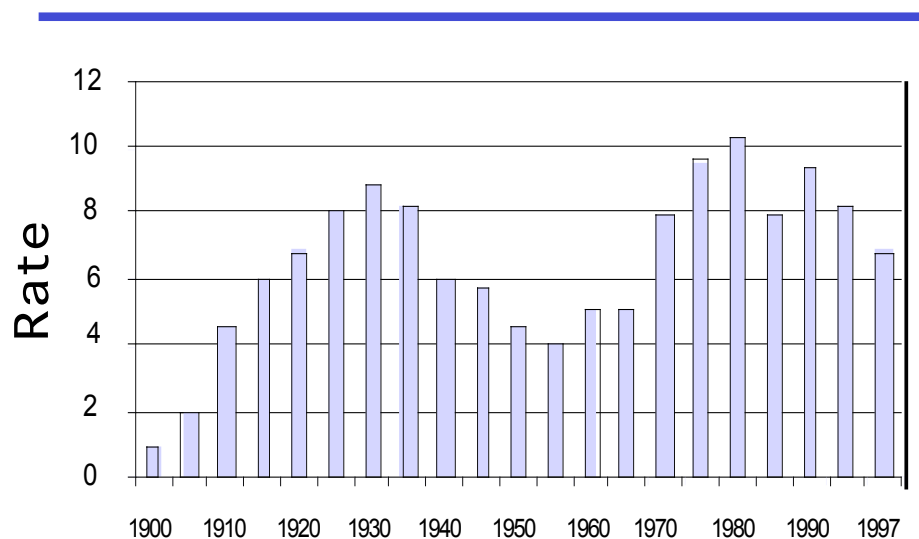

Figure 14.1. A century of murder

Approximate Homicides/100,000

in 1995 for Several Countries

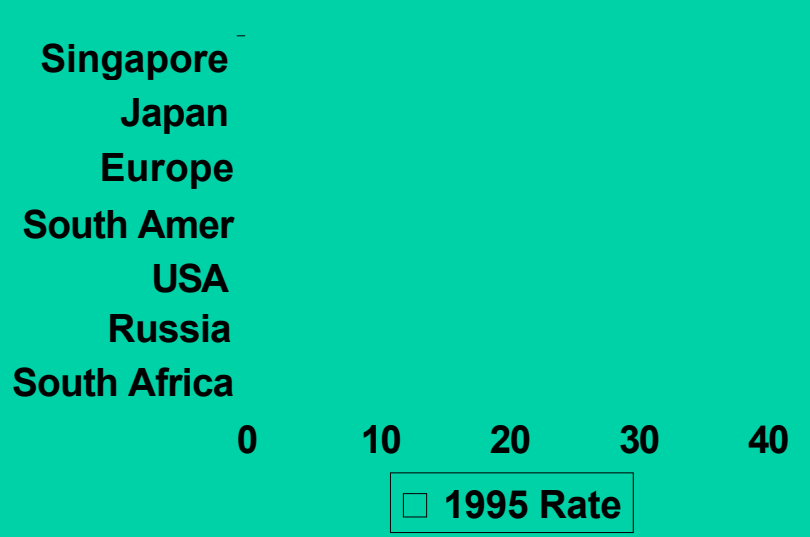

Figure 14.2 Homicide rates in 1995 in selected countries

violent crimes per 100,000 population according to the US Department of Justice's (1992) national victimization survey. Few other countries regularly conduct comparable victimization surveys, but they have been done in the UK. These surveys show that, contrary to popular belief, on average, the UK is now more dangerous than the United States. Overall violent crime rates (excluding homicide) are higher in the UK than in the United States (Farrington, 1999) for every violent crime except homicide, which are probably higher in the United
States simply because of the easier availability of guns.

\section{Multidisciplinarity of research}

The study of aggressive and violent social behavior has attracted a diverse set of researchers. Although our focus is on social psychological theory and research, it would be a mistake to ignore important studies and theories from criminology, psychiatry, 
biology, and other branches of psychology. Furthermore, we believe that one cannot understand the social psychology of aggressive behavior without placing it in a developmental context of differing social cognitive processes at different ages (Coie and Dodge, 1998). Aggressive behavior occurs in adults and children, but in different manifestations. An important task in understanding the social psychology of aggression is mapping the relations between adulthood and childhood aggression.

Nonetheless, like most social psychologists, we believe it is valuable to conceive of aggressive behavior (and most human characteristics) as occurring on a continuum. In this chapter, we avoid the less fruitful tendencies of some clinical, psychiatric, and criminological researchers to study aggressive behavior mostly in terms of categories of individuals (for example, conduct disordered or not, aggressive or not, violent or not), or overly restrictive definitions of aggressive behavior (for example, counting only violent crimes as aggression).

\section{TYPES OF AGGRESSION}

Scholars from different fields and different eras use different definitions of key concepts. In this section, we identify some key distinctions and recent changes.

\section{Aggression versus violence}

Like most psychologists, we define human aggression as behavior directed toward another individual carried out with the proximate (immediate) intent to cause harm. Furthermore, the perpetrator must believe that the behavior will harm the target, and that the target is motivated to avoid the behavior. Actual harm is not required. (For detailed discussions, see Baron and Richardson, 1994; Berkowitz, 1993; Bushman and Anderson, 2001; Geen, 2001.)

Violence is physical aggression at the extremely high end of the aggression continuum, such as murder and aggravated assault. All violence is aggression, but much aggression is not violence. For example, one child pushing another off a tricycle is aggression, but is not violence. A school shooting is both aggression and violence. Some criminologists and public-health officials use quite different definitions of violence, and seem largely uninterested in aggression or the aggression-violence continuum (Surgeon General, 2001). For some, "violence" requires actual serious physical harm to another person and it must be illegal. Such a definition may be valuable for epidemiological purposes, but for understanding the processes underlying the behavior it is inferior to the social psychological definition.

\author{
Physical, verbal, direct, and \\ indirect aggression
}

The difference between physical and verbal aggression is obvious. Less obvious is the distinction between direct and indirect aggression that emerged in the late 1980s (Lagerspetz et at., 1988). ${ }^{I}$ Indirect aggression is committed outside the presence of the target, such as telling stories and lies behind someone's back to get them in trouble or taking a person's things when they are not there. Direct aggression is committed in the presence of the target. Substantial evidence suggests that females are more likely to engage in indirect forms of aggression, males are more likely to engage in direct physical aggression, and both genders are about equally likely to engage in verbal aggression (Bjorkqvist et at., 1992; Crick and Grotpeter, 1995; Lagerspetz et at., 1988; Lagerspetz and Bjorkqvist, 1992).

\section{Dimensions versus categories of aggression}

Traditional discussions of aggression draw a series of dichotomous distinctions between types of aggression. The main dichotomies are affective versus instrumental, impulsive versus premeditated, and proactive versus reactive. These dichotomies are typically conceived in overlapping ways, leading to some confusion. Affective aggression (also labeled 'hostile' [Feshbach, 1964], or 'emotional' [Berkowitz, 1993]) is usually conceived as impulsive, thoughtless (that is, unplanned), driven by anger, having the ultimate motive of harming the target, and occurring in reaction to some perceived provocation. Instrumental aggression, in contrast, is usually conceived as a premeditated means of obtaining some goal other than harming the victim, being proactive rather than reactive, and resulting from cold calculation rather than hot affect. Impulsive aggression is usually conceived as thoughtless (automatic, fast, and without consideration of consequences), reactive, and affect laden. Premeditated aggression, in contrast, is usually conceived as thoughtful (deliberative, slow, and instrumental), proactive, and affect-less. Proactive and reactive aggression are frequently used interchangeably with instrumental and affective, but they have slightly different emphases. Proactive aggression is usually conceived as occurring without provocation, is thoughtful, and has little or no affect. Reactive aggression is a response to a prior provocation and usually is accompanied by anger (Dodge and Coie, 1987; Pulkkinen, 1996).

When taken too literally, these dichotomies create many conceptual and empirical problems. Apparently instrumental aggression can also contain much hostile affect; some angry outbursts 
appear to be coldly calculated, some proactive aggression has a distinctly emotional aspect, and instrumental considerations of potential consequences can be made both automatically and without awareness (Anderson and Bushman, 2002a; Bushman and Anderson, 2001). For example, frequent use of aggression to obtain valued goals can become so automated or habitual that it becomes impulsive (Bargh and Pietromonaco, 1982; Schneider and Shiffrin, 1977; Shiffrin and Schneider, 1977).

We believe that it is more useful explicitly to abandon strict dichotomies in favor of a dimensional approach. Any aggressive act can therefore be characterized along each of the following dimensions: degree of hostile or agitated affect present; automaticity; degree to which the primary or ultimate goal is to harm the victim versus benefit the perpetrator; and degree to which consequences were considered. (Intention to harm is still seen as a necessary proximate goal of all aggression.) This approach yields a clearer understanding of mixed motive aggression, quick but consequence-sensitive aggressive acts, and other forms of aggression that have been problematic for traditional dichotomous approaches (Anderson and Bushman, 2002a; Bushman and Anderson, 2001).

\section{Situation versus person causes of aggression}

One final dichotomy deserves special attention because of its prevalence throughout modern social and personality psychology as well as historical and modern theories of aggression - the distinction between personological and situational factors. Personological causes include whatever the person brings to the current situation, factors such as attitudes, beliefs, and behavioral tendencies. Situational causes are features of the present situation that increase (or inhibit) aggression, factors such as an insult, uncomfortable temperature, presence of a weapon, or presence of one's religious leader. Both types may be conceived as proximate causal factors, because both are present in the current situation. All social behavior, including aggression, is the result of the convergence of both types of factors. Situational factors (that is, instigators or inhibitors of aggression) and personological factors (that is, propensity or preparedness to aggress) combine in complex ways to determine what type of behavior will emerge. The right situation can provoke most people to behave aggressively, but some people are much more likely to aggress than others.

\section{AGE AND GENDER TRENDS}

Regardless of the particular epoch or particular country, age and gender predict the likelihood of different types of aggressive and violent behavior. Figure 14.3 presents US 1990 arrest rates for murder separately by age and gender. Males are much more likely to be violent aggressors at any age, but for

Arrest rates for murder and nonnegligent manslaughter (1990)

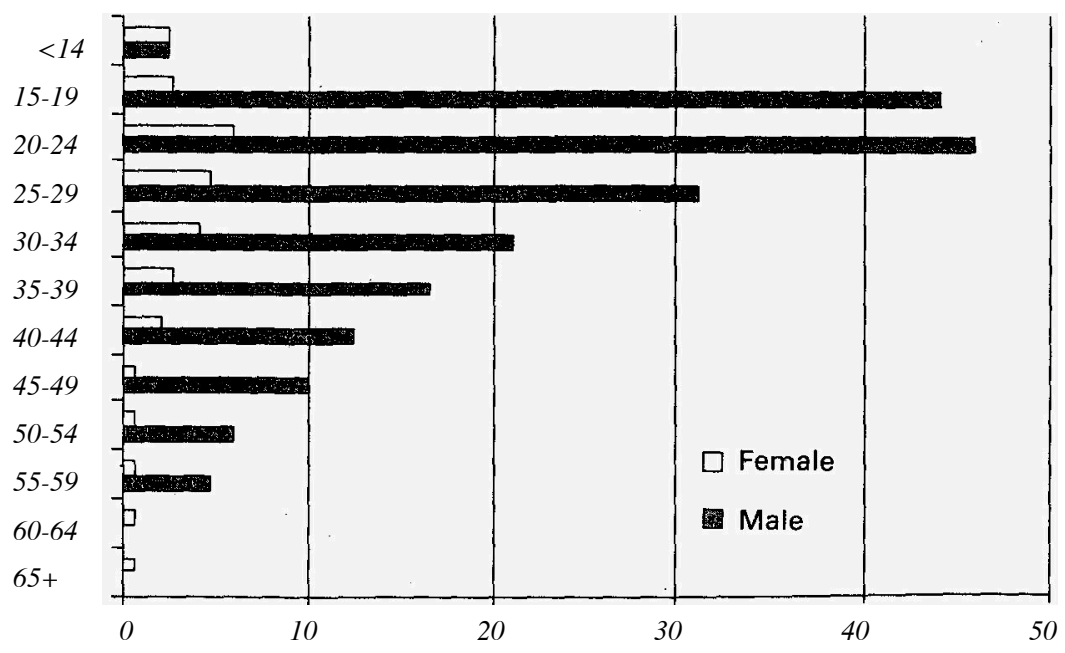

Figure 14.3Arrest rates for homicide in the USA in 1990 
both males and females the age effect is dramatic; the highest incidence of violence occurs between 15 and 35 (US Department of Justice, 2001).

\section{Emergence of aggression in early childhood}

Angry affective responses revealed by facial expressions (Ekman and Friesen, 1975) are apparent in most infants before any aggressive behaviors are noticeable, as early as at $4-7$ months (Stenberg et al., 1983; Stenberg and Campos, 1990). However, aggressive behavior appears shortly afterwards. Provocations by other infants (such as grabbing toys) result in protest and aggressive retaliation by the age of 1 year (Caplan et al., 1991). Conflict physical aggression is frequent in peer interactions at ages 1-3 (Loeber and Hay, 1993; Shantz and Shantz, 1985; Tremblay et al., 1996), usually to obtain instrumental goals. Epidemiological studies have shown rates of about 10 percent for peer fighting problems in 3-year-olds (Earls, 1980). In the preschool and early elementary years, physical aggression generally decreases while verbal aggression increases (Loeber and Hay, 1997; Tremblay, 2000). For most normal people, the age trend for physical aggression is downward after age 3 (Tremblay, 2000; Tremblay et al., 1996) as they are socialized out of behaving aggressively.

Some children, however, increase in aggressiveness as they age. Although the toddler years are the period of greatest aggression for most children, the most dangerous years for this subset of individuals (and for society) are late adolescence and early adulthood. Not only are these individuals behaving objectively more aggressively than at earlier ages, but at this age weapons are used more frequently, and the consequences are more severe (Cairns and Cairns, 1994; Verlinden et al., 2000).

Although these generalizations summarize the empirical data accurately, the many different ways one can assess violence and aggression allow for many deviations from this general picture. Grabbing toys, physical fighting, telling lies to get others in trouble, and taking others' things all may show different trajectories. Farrington (1993) proposed that aggressiveness can best be measured by different constructs at different ages; for example, fighting at age 8 , vandalism at age 12 , and homicide at age 18. Huesmann et al. (1984a) propose that a latent construct of aggressiveness manifests itself in different ways at different ages. Additionally, different contexts may influence the growth of aggression quite differently. For example, Guerra et al. (1995) reported that in high-risk inner-city schools, average aggression by children increases dramatically during the first year of school. Similarly, the prevalence of a gang culture in the child's environment may radically alter the growth curve of aggressive behavior (Goldstein, 1994).

\section{Emergence of gender differences}

Gender differences in aggression are very noticeable by the preschool years (Loeber and Hay, 1997), with boys showing higher levels of physical aggression than girls. However, many girls are physically aggressive at this age, and, on average, girls show levels of verbal and indirect aggression similar to or greater than boys (Crick and Grotpeter, 1995; Rys and Bear, 1997). In later elementary grades and adolescence, gender differences increase. Indirect aggression becomes much greater for girls than boys, physical aggression becomes much greater for boys than girls, and both genders become about equally likely to engage in verbal aggression (Bjorkqvist et al., 1992; Crick and Grotpeter, 1995; Lagerspetz et al., 1988; Lagerspetz and Bjorkqvist, 1992). These gender differences culminate in dramatic differences in physically violent behavior in young adulthood, reflected by the different homicide rates shown in Figure 14.3. Nevertheless, this should not lead one to believe that females are never physically aggressive. Straus (1997) in surveys and Archer (2000) in a metaanalysis have convincingly demonstrated that in aggression between domestic partners, females are slightly more likely to use physical aggression against their partners than are males! Although males are more likely to inflict serious injury on their partners, females inflict 35 percent of serious injuries and 44 percent of deaths.

Laboratory studies with college students often yield higher aggression by males, but provocation apparently has a greater effect on aggression than does sex. Bettencourt and Miller's (1996) metaanalysis found that sex differences in aggression practically disappear under high provocation.

Developmental research suggests that many gender differences in aggression result both from different socialization experiences (White, in press) and from innate physical, neurological, and hormonal differences. We discuss these innate factors in more detail below, but their obvious relevance has led to substantial evolutionary theorizing about the reasons for gender differences in aggression (Campbell, 1999; Geary, 1998). For example, Geary et al. (1995) and Buss and Shackelford (1997a, 1997b) have offered evolutionary reasons for why males are more upset by sexual infidelity of their mates than by emotional infidelity, whereas the opposite pattern occurs for females, and for why males are more likely to use violent tactics to retain their mates. Additionally, Malamuth and Heilmann (1998) have proposed a comprehensive evolutionary theory for sexual aggression. 
Continuity of aggression from childhood to adulthood

By the preschool and early elementary years, individual differences in the propensity to behave aggressively are apparent (Eron et al., 1971; Huesmann et al., 1984a). Such early differences are highly predictive of later aggressive behavior, even for the eventual offspring of these aggressive children (Farrington, 1982; 1995, 2002; Huesmann et al., 1984a; Huesmann and Moise, 1998; Loeber and Dishion, 1983; Magnusson et al., 1975; Olweus, 1979). Continuity coefficients range from 0.76 for 1 year to 0.60 for 10 years for both males and females (Olweus, 1979). Huesmann et a!. (1984a) report 22-year disattenuated continuity coefficients of 0.50 for males and 0.35 for females. This is not simply a case of a few highly aggressive children remaining aggressive while others change radically. The continuity occurs all along the range of aggression (Huesmann and Moise, 1998). Of course, many aggressive children become nonviolent adults. However, it is rare for severe, habitual aggressive behavior to appear suddenly in late adolescence or adulthood (Brame et al., 2001).

\section{RECENT THEORETICAL DEVELOPMENTS}

For social psychologists, probably the most notable theoretical development of the 1980s and 1990s was the emergence of social-cognitive models. Social learning and social cognitive theorists (e.g., Bandura, 1973, 1983, 1986; Mischel, 1973) set the stage for this advance with the view that social behavior moves under the control of internal, self-regulating processes. What is important is the cognitive evaluation (construal) of events taking place in the child's environment, how the child interprets these events, and how competent the child feels in responding in different ways. These cognitions provide a basis for stability of behavior tendencies across a variety of situations, but coupled with frequent situational specificity. Internalized standards for behavior are developed from information conveyed by a variety of sources of social influence, including conditioning and observational learning.

Berkowitz $(1989,1993)$ added another important dimension with his 'cognitive neoassociationist view' of aversively stimulated aggression. While not disputing the importance of internalized standards, Berkowitz emphasized the importance of enduring associations between affect, cognition, and situational cues. Aversive stimulation produces initially undifferentiated negative affect. However, this negative affect and other situational cues prime a network of cognitive structures that influence the evaluation of the meaning of the negative affect and the aversive stimulus. A person's eventual behavior and emotions depend on this cognitive process.

\section{Social-cognitive, information-processing models of aggression}

Three specific information-processing models have emerged from these developments, proposed respectively by Anderson (Anderson et al., 1996; Anderson and Bushman, 2002a; Anderson and Dill, 2000), Dodge (1980, 1986; Crick and Dodge, 1994), and Huesmann (1982, 1986, 1988, 1998). Although varying in their focus, terminology, specificity, and scope, these models all adopt similar premises about the processing of information in social problem solving, the social-cognitive structures involved, the interacting role of emotions and cognitions, and the interaction of person and situation. These models have provided a coherent way to think theoretically about aggression, and have also stimulated substantial research.

These models are based on the assumption that human memory can be represented as a complex associative network of nodes representing cognitive concepts and emotions. Experience leads to the development of links among elemental nodes. Sets of concepts that are strongly interconnected are known as knowledge structures. The activation of a simple node or a more complex knowledge structure at any time is determined by how many links to it have been activated, as well as the strength of associations among the activated links. When total activation is above threshold, the knowledge structure is activated, 'experienced', and used. When a stimulus increases the activation level but does not fully activate the knowledge structure (that is, it is still below threshold), the stimulus is said to have 'primed' the knowledge structure.

Knowledge structures influence perception at multiple levels, from basic visual patterns to complex behavioral sequences. Knowledge structures are used to guide people's interpretations and behavioral responses to their social (and physical) environment. They contain (or are linked to) affective states, behavioral programs, and beliefs (including beliefs about likely consequences), and can become automated with use.

Four macroprocesses in social problem solving are as follows: (1) encoding and interpretation of environmental cues; (2) generation and selection of goals, behaviors, or scripts to guide behavior; (3) evaluation of the selected script for appropriateness on several dimensions; and (4) behavioral enactment followed by interpretation of the response of others. Emotional state affects these processes, and can be changed by the outcome of these processes. Furthermore, because affect can be a part 


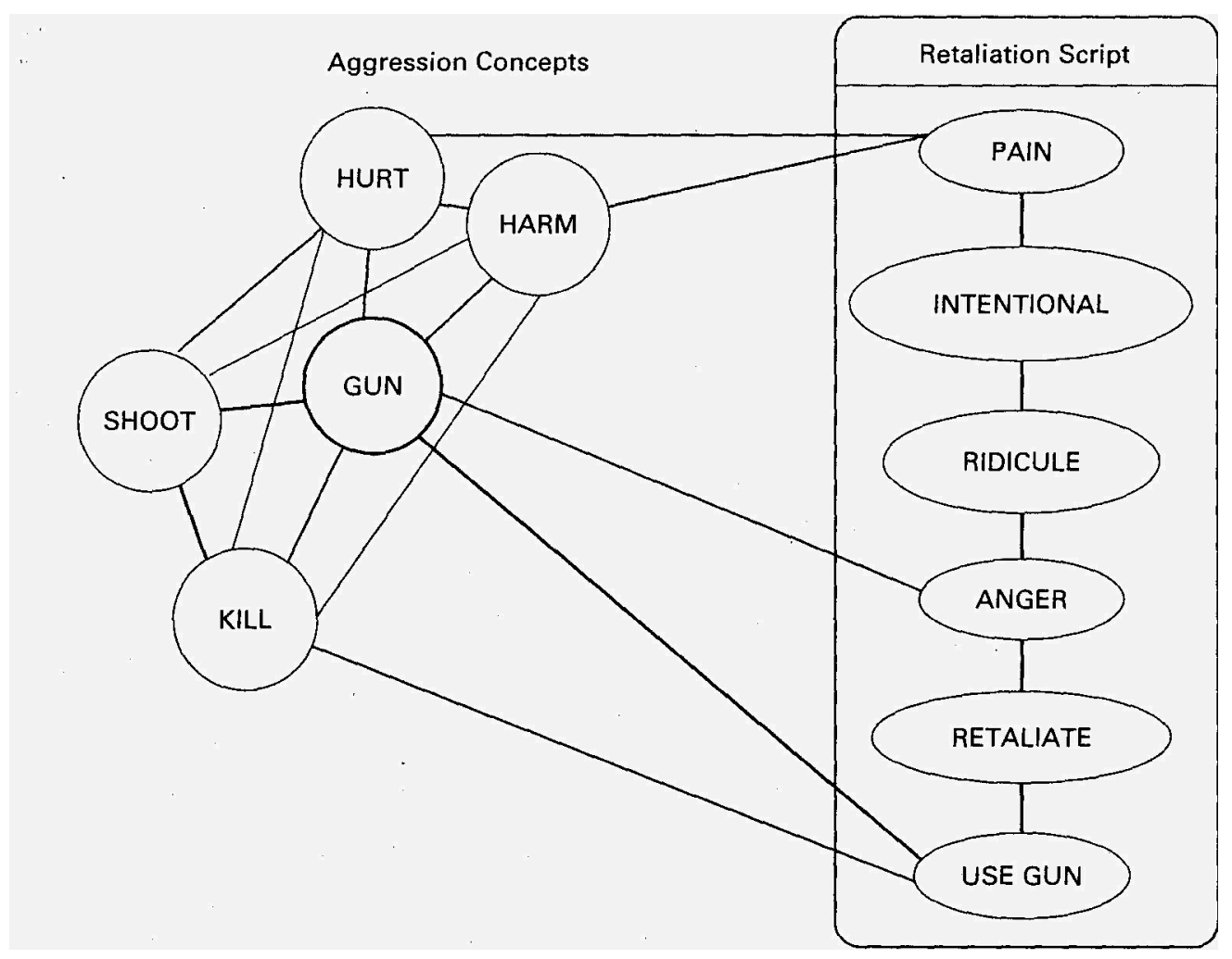

Figure 14.4 Simplified associative network with aggression concepts and a retaliation script (from C.A. Anderson et al.. 1998)

of the knowledge structure network, current emotions can directly prime specific knowledge structures and thereby influence which schemata are brought to bear on the present situation.

Figure 14.4 displays two simplified types of knowledge structures from an associative network perspective, a general schema about guns, and a behavioral script for retaliation. In general, concepts with similar meanings (such as hurt and harm) and concepts that are frequently activated simultaneously (such as gun and shoot) become strongly associated. In Figure 14.4, thicker lines represent stronger associations and shorter distances represent greater similarity of meaning. The figure also illustrates how network associations can activate particular knowledge structures. For example, if the nodes 'gun', 'kill', 'hurt', and 'harm' are activated, the retaliation script would be strongly primed; a situation that is ambiguous with regard to whether one has been ridiculed would more likely be interpreted as a provocation warranting retaliation.

All of the social-cognitive models agree that aggression results from the way in which person variables and current situational variables combine to influence the individual's present internal state. Sometimes person and situation variables combine interactively, as in K.B. Anderson et al.'s (1998) finding that pain and trait hostility interactively affect aggressive cognitions. Figure 14.5 illustrates this point with the general aggression model schematic. The present internal state then influences a host of appraisal and decision processes (see Anderson and Bushman, 2002a, for more detail). Eventually (sometimes very quickly), an action emerges, which in turn moves the social encounter along to its next cycle.

From the social-cognitive perspective, personality is the sum of a person's knowledge structures (Mischel and Shoda, 1995; Sedikides and Skowronski, 1990). How people construe and respond to their world depends upon the particular situational factors in their world and on the knowledge structures they have learned and habitually use. Situational realities impose constraints on how people construe their world, but individual differences in the structure, accessibility, and use of underlying knowledge structures create a range of possible construals. In this view, personality results 


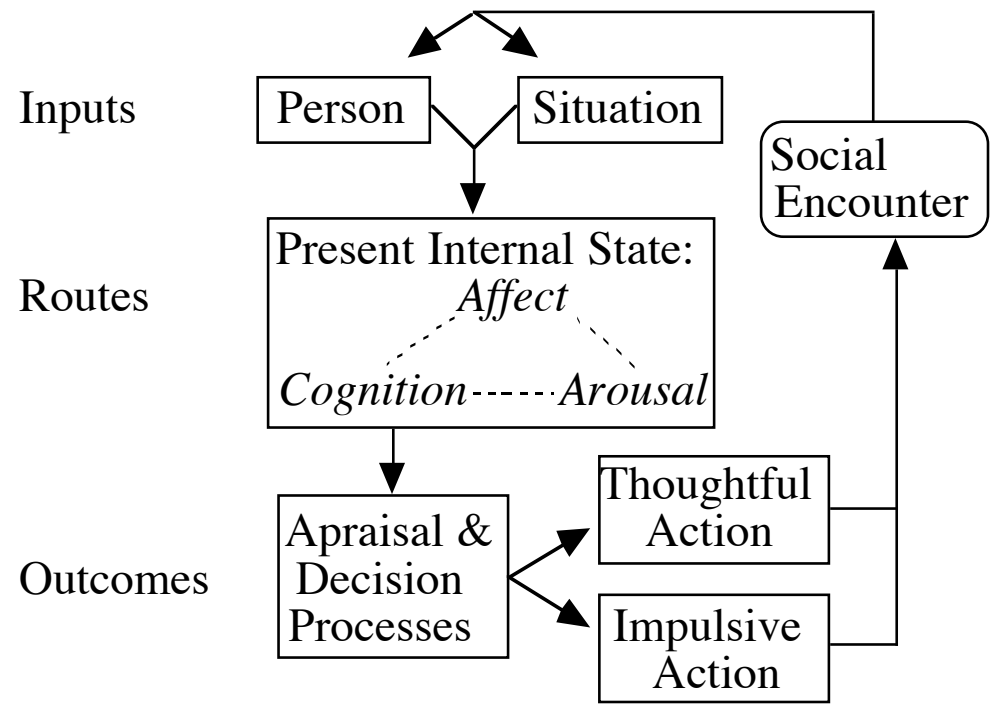

Figure 14.5 The general aggression model episodic processes (from Anderson and Bushman, 2002a)

from the development and construction of knowledge structures, based primarily on life experiences, but including biological influences as well.

Research has shown that the process by which hostile schemas or aggressive scripts - indeed, all types of knowledge structure - are activated is cognitive but can with practice become completely automatic and operate without awareness (Schneider and Shiffrin, 1977; Todorov and Bargh, 2002). One can view each episodic cycle depicted in Figure 14.5 as a learning trial, leading to the development of well-rehearsed (and eventually automatized) knowledge structures of various kinds. The socialcognitive information-processing model implies systematic information processing, but it does not imply that such processing must be conscious and controlled.

\section{Biosocial interactions}

Another important theoretical movement has been toward models that integrate the effects of predisposing biological factors with the effects of environmental social influences. According to the emerging interactionist perspective, inherited biological factors clearly influence the risk of aggression, but do not determine aggression (Raine et al., 1997). Raine introduced the term 'biosocial interactions' to refer to the view that biological predispositions manifest themselves through 'interactions' with the social context in which the organism develops. Thus, the effects of biological processes are included in social-cognitive models through their influence on knowledge structures (such as scripts, beliefs, and schemas) and through their influence on affective components.

A related movement is the emergence of more sophisticated evolutionary theorizing about aggression, and the recognition of the importance of 'calibration' through learning experiences in the emergence of inherited behavior patterns (e.g., Buss and Shackelford, 1997b; Daly and Wilson, 1994; Malamuth and Heilmann, 1998). Similarly, learning is now viewed by many social-development researchers as a process through which behavioral predispositions are modified as children are socialized via conditioning and observational learning (Huesmann, 1997; Tremblay, 2000).

Along these same lines is the concept of 'preparedness' (Seligman, 1970), the idea from the animal-learning literature that it is easier to link some stimulus-response pairs than others. One well-known example of a 'prepared' connection is food aversions. Preparedness relates to human aggression in two ways. First, certain emotional states and behavioral syndromes appear to be easily linked (e.g., Berkowitz, 1993). Humans appear to develop links easily between frustration, pain and anger, and aggression. Second, biological effects on development of aggressive personality may work by preparing some individuals to learn more easily frustration-anger-aggression linkages, and by preparing others to learn more easily the negative consequences of aggression (e.g., Soubrie, 1986). 


\section{CAUSES OF AGGRESSION}

Research over the past several decades has suggested a wide variety of causes of cyclical increases and decreases in violence, of age trends in violence, and of differences in violence between societies and genders. For example, the increased accessibility of guns (O'Donnell, 1995,) global warming (Anderson et al., 1997), different cultural norms about violence (Nisbett and Cohen, 1996)2, and the widespread exposure to violent entertainment media (Bushman and Huesmann, 2000) all probably contribute to the high level of violence and aggression in modem societies and to differences between societies. However, severe aggressive and violent acts rarely occur unless there is a convergence of multiple, precipitating situational instigators and multiple, predisposing personological characteristics. No one causal factor by itself can be expected to explain more than a small portion of individual differences in aggressiveness. Nevertheless, accumulating empirical evidence reveals that several fundamental social psychological processes that operate among all people at all times explain a lot of the individual differences in aggression and violent behavior, and how situational factors interact with individual predispositions to increase and decrease aggression and violent tendencies. Aggression is most likely to develop in children who grow up in environments that reinforce aggression, provide aggressive models, frustrate and victimize them, and teach them that aggression is acceptable. The acquired scripts, schemas, and beliefs (that is, knowledge structures) are most likely to produce aggression when situational factors instigate aggression.

As noted earlier, and as illustrated in Figure 14.5, two types of proximate causes of aggression interact in the present situational context, situational instigators and personal preparedness to aggress. In the following sections, we briefly review these two types of causal factors.

There are also two types of distal causal factors. These are environmental and biological modifiers of personal preparedness to aggress. Typically, they exert their influence over a long period of time, and operate by increasing proximate factors that facilitate aggression or decreasing proximate factors that inhibit aggression. For example, repeated exposure to media violence can create highly accessible retaliation scripts that are easily activated on future occasions. Of course, some modifiers may operate in both a short-term and a long-term manner. Exposure to a violent movie both primes aggressionrelated knowledge structures in the immediate situation and constitutes an additional learning trial that teaches the viewer beliefs that will have longlasting effects.
Situational instigators

\section{Aversive condition}

One of the most important classes of instigators is aversive stimulation. Berkowitz (1982, 1993) proposed that any aversive stimulation increases negative affect, which, in turn, increases the likelihood of aggression. Hostile aggression, almost by definition, requires aversive stimulation producing negative affect. However, Instrumental aggression may occur without an instigation to negative affect. Yet, instigation of negative affect can also increase instrumental aggression. A large class of stimuli have been found to increase the likelihood of aggression by increasing the negative emotion we label as anger.

Provocation is undoubtedly the strongest situational instigator of human aggression (Berkowitz, 1993; Geen, 2001). Provocations include insults, slights, other forms of verbal aggression, physical aggression, interference with one's attempts to attain an important goal - the list is almost endless. But provocation is 'in the eye of the beholder'. Some things that are provoking to one individual are not provoking to another. Indeed, this is one of the key ways that situational and personological factors interact. For example, certain subcultures develop codes of honor or personal respect that influence aggression by influencing what is considered provocative (Horowitz and Schwartz, 1974; Nisbett and Cohen, 1996), and different individuals react differently to threat (Baumeister and Boden, 1998; Baumeister et al., 1996).

Why is provocation such a robust instigator to aggression? Research suggests that humans obtain gratification from hurting those who provoke them. Baron (1977) varied whether experimental participants received information about whether their aggression was hurting another person. When the target person had not provoked the participant, receiving feedback that their aggression hurt the target reduced participants' aggression. But when the target person had seriously provoked the participant, feedback that the aggression hurt the target led to further increases in aggression. Baron concluded that humans, when provoked, do have a desire to hurt (see also Berkowitz, 1993).

Frustration is the classical aversive instigator (Dollard et a!., 1939). Frustration can be defined as the blockage of goal attainment. Most frustrations are also viewed as provocations because a person is identified as the agent responsible for goal blockage. Research from several domains supports the early notion that frustration can increase aggression even when the frustrating agent is unknown, or is blameless, or is not the target of subsequent aggression, or is not even another human (Berkowitz, 1993). For example, frustrations that are fully justified increase aggression against the frustrating 
agent (e.g., Dill and Anderson, 1995), and against a person who was not responsible for the failure to attain the goal (e.g., Geen, 1968). Recent work has shown that displaced aggression, wherein the target of aggression is not the person who caused the initial frustration, is a robust phenomenon (MarcusNewhall et a!., 2000; Pedersen et al., 2000).

Pain and discomfort in animals is a strong instigator to aggression even against targets not connected to the pain (Ulrich, 1966). Similarly, research with people has shown that even nonsocial aversive conditions (for example, hot temperatures, loud noises, and unpleasant odors) increase aggression (Baron, 1977; Griffit, 1970; Jones and Bogat 1978). Acute aversive conditions, such as pain produced by immersing a hand in a bucket of ice water increases aggression (e.g., Berkowitz, 1993; Berkowitz et al., 1981). General discomfort, such as that produced by sitting in a hot or cold room (Anderson et a!., 2000) can also increase aggression. Criminological data consistently show that violent crime rates are higher when the temperature is higher (Anderson, 1989), and there is even evidence that general trends in global warming are correlated with trends in aggression (Anderson, 2001; Anderson et al 1997).

Bad moods produce negative affect, and thus serve as an instigation to aggression (Berkowitz, 1993). This has been found in clinical studies of children (Pfeffer et al., 1987; Poznanski and Zrull, 1970). Additionally, inductions of depressive moods are accompanied by increases in aggressiveness (Berkowitz and Troccoli, 1990; Miller and Norman, 1979).

Social stress can also instigate aggression Landau (1988) showed that general social stress in Israel is related to levels of violent crime. Guerra et al. (1995) showed that higher levels of life stress among Chicago children was related to increased aggression.

Priming aggressive cognitions and affect

A second class of situational instigators consists of stimuli that prime aggressive cognitions or negative affective states and thus increase the likelihood of aggression. By 'prime', we mean that the stimulus raises the activation level of a relevant knowledge structure, thereby making it more likely to be subsequently activated.

Numerous stimuli can serve as aggression primes. For instance, Berkowitz and LePage (1967) found that the mere presence of a gun (versus a tennis racket) increased the aggression of angered research participants. Later reviews (e.g., Berkowitz and Donnerstein, 1982; Carlson et al., 1990) confirmed the phenomenon in a variety of field and laboratory settings. A recent meta-analysis found that a weapon can prime aggression even without provocation (Bettencourt and Kernahan, 1997). More recent research has found that weapons automatically prime aggressive thoughts (C.A. Anderson et al., 1998). Initially, neutral stimuli may become primes for. aggression through learning. Leyens and Fraczek (1983) showed that the color of a room that was associated in the past with aggression could prime later, aggression. The immediate increase in aggression after exposure to media violence may also result in, part. from the priming of aggressive thoughts, feelings, and scripts (Anderson, 1997; Bushman and Huesmann, 2000).

Priming is an automatic process that can occur without conscious awareness. For example, people exposed subliminally to aggressive words subsequently rate a target person as more aggressive (Bargh and Pietromonaco, 1982), presumedly because well-practiced schemata involving aggression were primed. Stereotypes can also operate automatically. Devine (1989) showed that people primed subliminally with nonaggressive words closely related to the African-American culture were relatively more likely to ascribe aggression to a target person. Automatic priming also works on behavioral scripts. Bargh et al. (1996) and Carver et al. (1983) have shown that solving anagram problems whose solutions are aggressive words increases the chances of aggressive (or rude) behavior immediately afterwards, at least if participants are provoked. Chen and Bargh (1997; Bargh et a!., 1996) also found that subliminal priming with African-American faces increases aggression.

Because priming activates associative pathways, automatic priming has been used to demonstrate subtle relations between aggression and other concepts. Zubriggen (2000) showed that men for whom sexual words primed power constructs were more likely to have engaged in aggression against women. Bargh et al. (1995) showed that power words primed recognition of sexual words for men who scored high on propensity to be sexually aggressive. Thus, power is an important component of motivation for sexual aggression in many men. Cognitive stereotypes about the aggressiveness of groups of people have also been shown to serve as automatic aggressive primes. For example, Payne (2002) demonstrated that priming people with a picture of an African-American increases the likelihood that they will correctly recognize a degraded picture as a weapon.

\section{Stimuli that arouse}

A third class of situational instigators are those that increase arousal level. There are at least three different ways that arousal can increase aggression. First, high general arousal energizes the dominant behavioral tendency (Berkowitz, 1993). If a person is provoked when arousal is already heightened, 
heightened aggression can result (Geen and $\mathrm{O}^{\prime} \mathrm{Neal}$, 1969). Second, arousal produced by one stimulus can be 'transferred' or 'misattributed' to another situational instigator by being misperceived as having been generated by it (Zillmann, 1979, 1983). Such misattribution or 'excitation transfer' effects can persist long after the original instigation, mainly because, once the instigation event has been perceived as anger-inducing, the person will remember it as a more serious transgression. Third, high arousal (and very low arousal) may themselves be aversive states, and may therefore increase aggression in the same manner as other aversive stimuli.

Factors that interfere with aggression inhibition

A fourth class of situational instigators consists of factors that interfere with cognitive processes that normally inhibit aggression.

High levels of arousal and stress seem to have such an effect. Attention is narrowed to a few salient cues (Broadbent, 1971; Easterbrook, 1959). Additionally, working memory capacity is reduced, memory search is narrowed, activation of weakly associated schemas becomes less likely, and the activation of the best-connected schemas and scripts becomes more likely (Anderson, 1990; Luria, 1973). Thus, threatening situations such as those containing provocations are likely to cue only aggressive interpretative schema and scripts.

Alcohol and other drugs have been linked to increased aggressive and antisocial behavior (Baron and Richardson, 1994; Berkowitz, 1993; Bushman, 1993; Murdoch et al., 1990), including homicide (Parker and Auerhahn, 1999), domestic violence (Wiehe, 1998), and sports violence (Russell, 1993). Some experimental studies suggest that alcohol causes an increase in aggressive behavior; however, alcohol's action on the brain mechanisms for aggressive behavior is modulated by genetic predispositions, learned expectations, social restraints, and cultural habits (Miczek et al., 1994: 406-7). The effects of other drugs on aggression are less clear, stimulants, depressants, opiates, and hallucinogens showing different effects in different studies. The body of empirical research on aggression and drugs and alcohol is too complex to disentangle in this chapter. However, the effects of such drugs on aggression appear to be a consequence of three processes: (1) disinhibition of behavior by the physiological effect of alcohol on serotonergic mechanisms (Brain, 1986), (2) cognitive myopia due to physiological effects on social-cognitive processing (Steele and Josephs, 1990; Taylor and Leonard, 1983), and (3) psychological disinhibition due to expectancy beliefs (Lang et al., 1975). One interesting finding from a meta-analytic review (Bushman, 1997) is that aggression-facilitating factors (such as provocation, frustration, and aggressive cues) have a stronger effect on people who are under the influence of certain types of drugs than on people who are not.

\section{Personal preparedness}

As described earlier, in the context of social-cognitive models of behavior, personality or 'the self' is viewed as the collection of cognitive structures and emotional tendencies that influence behavior in interactions with situational factors. Personal preparedness for aggression is represented by the extent to which those cognitive and emotional structures support aggression. 'Trait' measures of aggression seem either to assess past aggressiveness (e.g., Buss and Perry, physical aggression subscale, 1992) or assess these emotional and cognitive structures (e.g., Buss and Perry, hostility subscale, 1992; Caprara et al., 1994, 1985). In this section, we focus on research identifying specific elements of these relatively permanent cognitive and emotional structures that influence preparedness for aggression.

\section{Self-schemas}

Contrary to popular belief, low self-esteem is not a good predictor of aggression. Instead, individuals with inflated or unstable high self-esteem are the most prone to anger and are the most aggressive, especially when their high self-image is threatened (Baumeister et al., 1996; Bushman and Baumeister, 1998; Kernis et al., 1989). However, Lee et al. (2002) found that, for people of average selfesteem, negative self-evaluations in a self-esteemrelevant domain instigate prosocial behavior seemingly aimed at counteracting the negative evaluation.

Beliefs about oneself may also influence aggression by influencing script selection and evaluation. Self-schemas provide an internal context within which scripts must be evaluated. Heightened activation of self-schemas decreases the likelihood of aggression when the self-schema is nonaggressive (Carver, 1974), probably by filtering out potential aggressive scripts. Finally, there are theoretical reasons to believe that efficacy-related beliefs should be related to aggression, though the evidence of such associations is not strong (e.g., Bandura, 1977, 1986; McFall, 1982).

\section{Beliefs and attitudes about} appropriateness of aggression

Many beliefs seem to play a role in preparedness to aggress. Huesmann and Guerra (1997) have extensively studied the role of normative beliefs about aggression. Such beliefs consist of a person's 
perception about the appropriateness of aggression in particular contexts. In a study of urban children, they demonstrated that normative beliefs stabilize in the middle-elementary grades for most children. In the early grades, these beliefs were influenced by the children's aggressive behavior, but aggressive behavior was not influenced by the beliefs. However, by the fifth grade the children's aggressive behavior was influenced by their beliefs, and their behavior had less influence on subsequent beliefs. In another large sample study, Guerra et al. (1995). showed that these beliefs interacted with socioeconomic status (SES) and with neighborhood violence-induced stress. Children from low SES families typically showed greater acceptance of aggression and greater neighborhood-violence stress. In turn, the combination of such stress and beliefs approving of aggression was a potent predictor of subsequent aggression by the child. Huesmann and Moise (2002) have also shown that childhood exposure to media violence predicts adult normative beliefs more approving of aggression, which, in turn, predicts adult aggression.

Other researchers looking at different measures of cognitive approval of aggression have uncovered links to aggression (e.g., Gouze, 1987; Pakaslahti and Keltikangas-Jarvinen, 1996; Richards and Dodge, 1982; Slaby and Guerra, 1988). There are also substantial cultural differences in approval of aggression on many such measures. Fraczek (1985) studied youth in Poland and Finland and found different levels of approval of different kinds of aggressive acts (for defense, for gain, etc.). Fujihara et al. (1999) found similar approval levels for physical aggression among youth in Japan, Spain, and the United States, but different attitudes to verbal aggression. In a more recent study of Eastern and Western countries, Ramirez et al. (2001) discovered that verbal irony was considered relatively harmless in Spain, Poland, and the United States, but very aggressive in Japan and Iran. However, individual use of aggression to punish others was judged very acceptable in Japan and Iran, but not very acceptable in Spain, Poland, Finland, and the United States.

Attitudes to violence correlate with both mild and serious forms of aggression among youth and adults (e.g., C.A. Anderson et al., forthcoming; Bookwala et al., 1992; Kingery, 1998; Markowitz, 2001). Positive attitudes towards violence in general prepare certain individuals for aggression. More specific positive attitudes to violence against specific groups of people also increase aggression against those people. For example, attitudes to women are related to sexual aggressiveness against women (e.g., Malamuth et al., 1995). K.B. Anderson (1996) has further shown that males prone to aggress against women are not generally aggressive against all people in all situations; rather, they specifically target women (but not men) who have provoked them. Similarly, beliefs about punishment (Hyman, 1995), the need to squash children's challenges to adult authority (Azar, and Rohrbeck, 1986), and misconceptions about what children at various ages can do (Azar and Rohrbeck, 1986) all contribute to parental violence towards children.

\section{Hostile world schemas}

There are several ways in which hostile world schemas influence aggression. Aggressive individuals tend to perceive hostility in others where there is no hostility; that is, they display a hostile attributional bias (Dodge, 1980; Dodge and Coie, 1987; Dodge and Frame, 1982; Dodge et al., 1990; Graham and Hudley, 1994; Nasby et al., 1979; Slaby and Guerra, 1988; Steinberg and Dodge, 1983). Research on social perception (e.g., Fiske, 1982; Fiske and Taylor, 1991; Schneider, 1991), as well as aggression, suggests that hostile attributional biases are products of well-developed schemas. Dodge and Tomlin (1987) found that aggressive children rely on aggressive self-schemas and stereotypes to infer intent. Dill et al. (1997) found that aggressive college students perceive relatively more aggression in observed dyadic interactions, and expect others to behave more aggressively in hypothetical encounters. Zelli and Huesmann (1993) found that college students with greater ingrained persecution beliefs are more likely to perceive hostility when none is present. These hostile cue interpretations can become an automatic cognitive process (Bargh, 1989; Todorov and Bargh, 2002; Winter and Uleman, 1984; Zelli et al., 1995).

\section{Long-term goals}

Long-term, abstract goals influence the preparedness of the individual for aggression. For example, the overriding goal of some gang members is to be respected and feared (Horowitz and Schwartz, 1974; Klein and Maxson, 1989). Such a goal obviously colors one's perceptions of personally involving episodes, values, and beliefs about the appropriateness of various courses of action.

\section{Scripts}

Scripts include many different elements, such as goals, beliefs, and action plans. Research suggests that the most accessible social scripts for aggressive children and adults are aggressive ones. For example, scripts retrieved by more aggressive people to solve hypothetical problems incorporate relatively more physical aggression (Dill et al., 1997; Rubin et al., 1987, 1991; Waas, 1988). Priming by negative intent cues is more likely to activate an aggressive 
script in aggressive children (Graham and Hudley, 1994). Aggressive children are less likely to generate prosocial scripts to solve social problems (Deluty, 1981; Taylor and Gabriel, 1989), and there is some evidence that, as hypothesized, a narrower search process for a script is associated with more aggression (Shure and Spivac, 1980).

\section{Other knowledge structures}

The social-cognitive approach makes it clear that distinctions between traits, attitudes, beliefs, and goals are not as clear-cut or necessary as traditional textbook treatments of personality and social psychology might suggest. Most can be seen as variations of schematic knowledge structures. The importance of this becomes clearer when considering individual differences that do not. fit neatly into one of the standard categories, or when considering the explanatory power of certain types of individual differences. For example, take the well-established finding that trait aggressiveness, measured by selfreports of past aggressive behaviors, predicts future aggression in both laboratory and field settings. Unless one adopts a very behavioristic attitude, there is little explanatory power in this trait-aggression concept. However, the social-cognitive view suggests that the predictive power results from the fact that there are individual differences in knowledge structures that influence perceptions of intent, construals of appropriate ways of responding, and decisions regarding likely outcomes. These insights have all been borne out, and a deeper level of theorizing and explaining empirical relations results.

Individual differences in susceptibility to the weapons effect provides another useful example. The weapons effect itself is an example of a situational instigator, but recent work has demonstrated that both aggressive thoughts and aggressive behaviors prompted by the image of a weapon depend on both the type of person and the type of weapon (C.A. Anderson et al., 1998; Bartholow et al., forthcoming). Hunters have more extensive knowledge about hunting and assault rifles than nonhunters. Furthermore, hunters display relatively more positive affect, less aggressive thinking, and less aggressive behavior when a hunting rifle is present than when an assault rifle is present, but nonhunters show the opposite pattern. Hunter status is clearly an individual difference variable, one that indexes different life experiences, but it is not a personality trait, attitude, or even a belief. The social-cognitive approach provides a theoretical explanation for how such life experience variables influence the weapons effect, and subsequent studies have confirmed it.

The hunting example provides an excellent transition to our next section on environmental modifiers. These environmental variables influence a host of long-term person factors, such as personality traits, attitudes, scripts, and beliefs.

\section{Environmental modifiers}

These are environmental factors that exert longlasting effects by influencing what people learn, what they believe, and characteristic levels of mood. For example, parenting practices, community environments, culture, peers, exposure to violence, and socioeconomic level are all environmental modifiers by this definition. In all of these cases, observational learning plays a major role in the development of various knowledge structures that support aggression.

\section{Family, community, and cultural environment}

Children hear beliefs expressed by parents and peers, and observe parental and peer behaviors. From both types of observations, they draw inferences about the acceptability of aggression and violence. Thus, children's aggression beliefs tend to be correlated with those of parents (Huesmann et al., 1984a; Miller, 1991) and peers (Henry et al., 1996).

Whereas peers and family are the proximal influence in the socialization of young children, the community and culture exert influence through them and through direct connections to the child -schools, church, and mass media. Cultural variations in acceptance of aggression under various circumstances appear quite large. For example, K.L. Anderson (1990) has noted how subcultures of urban youth develop their own norms for behavior that emphasize aggression in many situations. In a series of field studies and experiments, Nisbett (1993; Nisbett and Cohen, 1996) has shown how southern-born males have adopted the normative beliefs of what Nisbett calls 'a culture of honor' and behave more aggressively in certain contexts. Cultural effects are also apparent in studies of immigrants. Souweidane and Huesmann (1999) found that the longer Lebanese immigrants were in the United States, the more they 'accepted' violence in general, but they became less accepting of violence by men against women.

Children who grow up observing or experiencing violence around them develop numerous problems (Osofsky, 1995). They behave more violently (Guerra et al., 1995) and are more likely to be physically aggressive against their own children later in life (Widom, 1989). Furthermore, recent research shows that such observations of violence seem to lead to the development of beliefs and scripts supporting aggression (Guerra et al., 2002).

Along these same lines is recent work on genocide and the failure of aggression inhibitions that normally operate in most people. Three research groups have independently identified and discussed how these inhibitions are sometimes overridden (Bandura et al., 1996; Keltner and Robinson, 1996; Staub, 1989, 1998). Most people do not commit extreme acts of violence even if they could do so 
with little chance of discovery or punishment. Such self-regulation may be due to the fact that people cannot escape the consequences that they apply to themselves. Self-image, self-standards, and sense of self-worth (that is, moral standards) are used in normal self-regulation of behavior. However, there appear to be at least two particularly important mechanisms that allow people to disengage their moral standards - moral justification and dehumanizing the victim. Moral justifications for extreme and mass violence include 'it is for the person's own good', it is for the good of society, or it is to satisfy the demands of personal honor. Such justifications can be applied at multiple levels, from child abuse to genocidal war. Dehumanizing the victim operates by making sure that one's moral standards are simply not applicable. War propaganda fits this mechanism, but people also use this mechanism at an individual level. Potential victims are placed in the ultimate out-group - one that has no human qualities (see also Diener, 1976; Prentice-Dunn and Rogers, 1983).

\section{Media violence}

Observation of violence in the mass media not only stimulates aggressive behavior in the short run by priming aggressive scripts and schemas, but also stimulates aggressive behavior in the long run by changing schemas, scripts, and beliefs about aggression. Undoubtedly, more research has been devoted to the influence of the mass media on aggression than to any other aspect of the cultural environment. As many researchers have shown, most recently in a meta-analysis by Anderson and Bushman (2002b), regardless of how one studies the media violence/aggression link, the outcomes are the same - significant, substantial positive relations. This is true for longitudinal studies, crosssectional correlational studies, field experiments, and laboratory experiments. Figure 14.6 displays the results of this meta-analysis. The effect sizes are substantial by public health standards (see Rosenthal, 1986). For example, the media violence/aggression relation is larger than the effects of calcium intake on bone density or the effect of condom use on reduced risk of HIV infection (Anderson and Bushman, 2002a). Because this literature is so huge, we highlight only a few points and direct readers to recent reviews of the $\mathrm{TV} / \mathrm{movie}$ violence literature (Bushman and Huesmann, 2000) and the video game violence literature (C.A. Anderson, 2002; Anderson and Bushman, 2001).

First, the evidence of a causal connection is now overwhelming, and has been strong since at least 1975 (Bushman and Anderson, 2001). The consistency of results regardless of design type, research group, media type, country of study, and control variables makes this one of the strongest research literatures in all of social and behavioral science. Alternative explanations generated by the lay public, media representatives, and professional naysayers have been examined and debunked many times. Yet, the general public seems to not have gotten the message, perhaps because of inaccurate news media reports (Bushman and Anderson, 2001).

Second, though the evidence of causality has been weakest for more extreme types of aggression, even in this restricted domain the overall pattern of results is strong. For ethical reasons, of course, one cannot randomly assign infants to low versus high 'media-violence-upbringing' conditions, and then follow them for 30 or more years to obtain measures of homicide and aggravated assault rates. However, the combination of cross-sectional, longitudinal, and intervention studies makes a convincing case for causal. effects on even extreme aggressive behaviors, especially when the results of field and laboratory experiments are also considered. For extremely aggressive behaviors, longitudinal studies with children provide the best tests of the plausibility of long-term effects. Only a few have been completed, but the results are quite consistent. In a study initiated in 1960 on 856 youths in New York State, Eron et al. (1972) found that boys' early childhood viewing of violence on TV was positively related to their aggressive and antisocial behavior 10 years later (after graduating from high school), even controlling for initial aggressiveness, social class, education, and other variables (Lefkowitz et al., 1977). A 22-year-follow-up of these same boys revealed that early aggression predicted criminality at age 30 and that early violence viewing was independently related to adult criminality (Huesmann, 1986, 1995).

A more representative longitudinal study was initiated by Huesmann and his colleagues in 1977 (Huesmann and Eron, 1986; Huesmann et al., 1984b). This three-year longitudinal study of children in five countries also revealed that the television habits of children as young as first-graders also predicted subsequent childhood aggression, even controlling for initial level of aggression. In contrast to earlier longitudinal studies, this effect was obtained for both boys and girls even in countries without large amounts of violent programming such as Israel, Finland, and Poland (Huesmann and Eron, 1986). A 15-year follow-up of the US children in this cross-national study revealed perhaps the strongest longitudinal effects of all (Huesmann et al., in press).Both boys and girls who had been high violence viewers in childhood behaved significantly more aggressively in their mid-20s; for males, this included being convicted of more crimes. Finally, a very recent study by Johnson et al. (2002) showed a significant effect of TV viewing at ages 14 and 22 on aggression in later adulthood. In all of these longitudinal studies, a large number of covariates (such as IQ, social class, parenting practices, and previous 


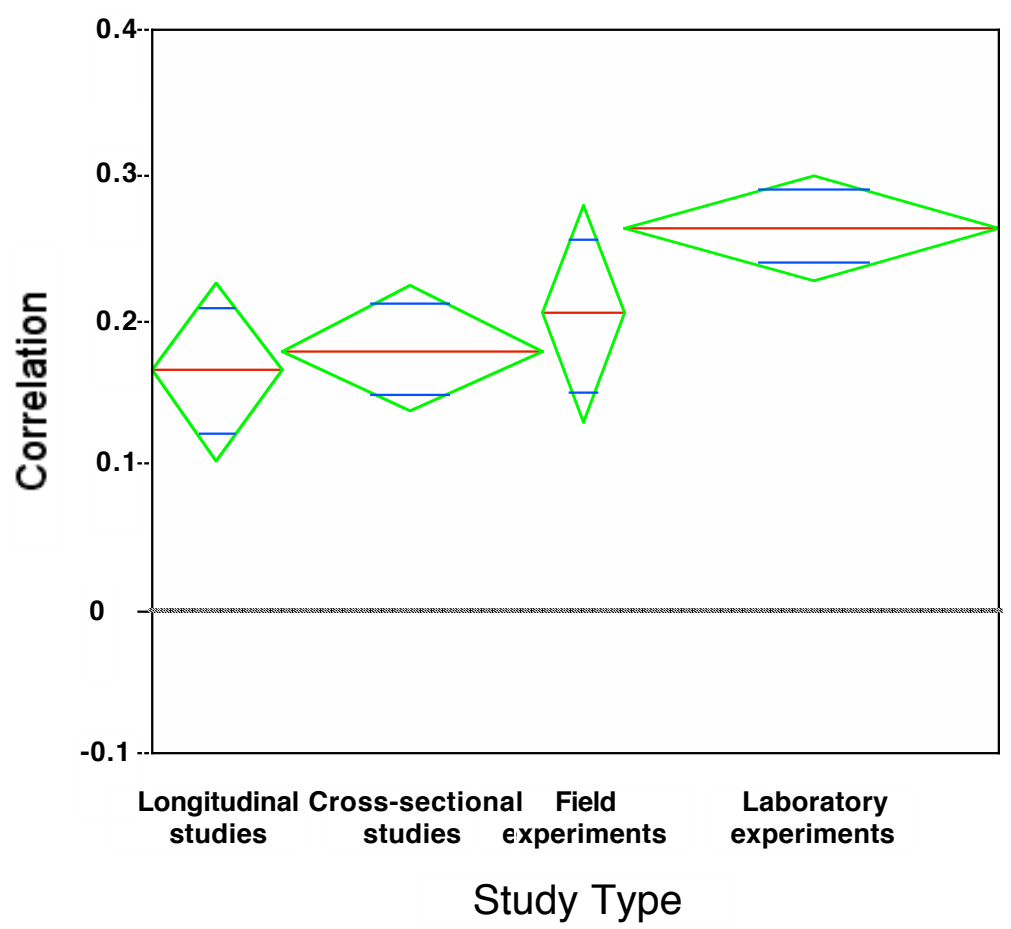

Figure 14.6 Effects of media violence on aggressive behavior (from Anderson and Bushman, 2002b). Diamond widths are proportional to the number of independent samples. There were 46 longitudinal samples involving 4,975 participants, 86 cross-sectional samples involving 37,341 participants. 28 field experiment samples involving 1,976 participants, and 124 laboratory experiment samples involving 7,305 participants. Red lines indicate the mean effect sizes. Blue lines indicate 95 percent confidence intervals. Note that zero (dashed line, indicating no effect) is excluded from all confidence intervals

level of aggression) were included in analyses and eliminated the possibility that the effects could be due to these 'third' variables. ${ }^{3}$

Third, both short-term and long-term media violence effects are now well understood. Research has found that exposure to media violence influences a host of theoretically important factors. For example, watching violent movie clips increases aggressive thoughts (e.g., Bushman, 1998), as does playing violent video games (e.g., Anderson and Dill, 2000). Exposure to violent media also desensitizes people to later violence, reducing physiological arousal to subsequent violence (e.g., Smith and Donnerstein, 1998; see also our following section on 'Low arousal'). Several studies have found that watching violent music videos increases viewers' acceptance and endorsement of violent behavior and attitudes (Greeson and Williams, 1986; Hansen and Hansen, 1989, 1990). One recent study has examined the effects of exposure to rap music videos on the attitudes of African-American adolescents. It found that participants exposed to violent rap music videos reported greater acceptance of the use of violence and increased probability that they would engage in violent behavior (Johnson et a!., 1995). Other research has linked self-reported fantasizing about aggression with peer-nominated aggression (Huesmann and Eron, 1986; Rosenfeld et al., 1982). Furthermore, both Viemero and Paajanen (1992) and Huesmann (Huesmann and Eron, 1986; Huesmann and Moise, 2002) found that viewing of TV violence predicts fantasizing about aggression, which in turn predicts later aggression. These and many other studies reveal that exposure to media violence modifies important aggression-related personological variables. 


\section{Maladaptive families/parenting}

Family variables have been linked to the development of life-long aggression (e.g., Patterson et al., 1989). Among the key problems they identified are parental use of poor disciplinary measures and inadequate monitoring of their children's activities. Similarly, Olweus (1995) identified a number of factors conducive to creating bullies: caretakers with indifferent attitudes towards the child, permissiveness for aggression by the child, and physical punishment and other power-assertive disciplinary techniques. Child abuse and neglect are themselves self-perpetuating problems. Abused or neglected children are particularly likely to become abusive and neglectful parents and violent criminals (e.g., Azar and Rohrbeck, 1986; Peterson et al., 1997) Recent prospective studies strongly suggest that corporal punishment of children leads to later increases in aggression against parents, peers, and dating partners (Straus, 2000).

\section{Extreme social environments}

As noted earlier, many social environments foster the development of aggressive personality. Such factors include poverty, living in violent neighborhoods, deviant peers, lack of safe child recreational areas, exposure to media violence, bad parenting, and lack of social support. Growing up in a culture of fear and hate, as in many ethnic minority communities around the world, may be the most extreme version of an aggression-fostering environment, and may well account for generations of ethnic and religious hatreds and genocidal tendencies that occasionally erupt into genocidal wars (Keltner and Robinson, 1996; Staub, 1989, 1998). All of these conditions facilitate the development of hostile interpretative schemata, the priming of existing hostile knowledge structures, and the chronic accessibility of such structures, and these structures may be strongly linked to a particular ethnic or racial out-group. It is easy to see how these factors operate via learning processes (including rewards for aggression), creating well-developed aggressive knowledge structures for perception, interpretation, decision making, and action. The perceptual knowledge structures modeled and explicitly taught in these contexts guarantee continued mistrust, misunderstanding, and hatred of key out-groups.

\section{Biological modifiers}

There is considerable evidence that a number of biological factors play a role in individual differences in preparedness to aggress. The exact mechanisms by which these factors produce aggressive people, in interaction with the person's environment, need additional study. Nonetheless, scholars in this area have already learned much.

\section{Low arousal}

Individuals with lower-than-average baseline levels of arousal seem to be more at risk of behaving aggressively. Rogeness et al. (1990) found that conduct-disordered children had lower baseline heart rates and blood pressure, and Raine (1993) reported low resting heart rates among antisocial children and adolescents. So-called psychopaths have long been known to have lower arousal as measured by EEG (Howard, 1984) or skin conductance (Hare, 1978). Indeed, Moise-Titus (1999) demonstrated that males who show depressed skin conductance and little negative emotion in response to seeing violence report having engaged in more aggression, and behave more aggressively in the laboratory. In a longitudinal study, Raine et al. (1990) assessed the heart rate, skin conductance, and EEG patterns of 101 15-year-old boys. Nine years later, they found significant relations between early low baseline arousal on each of the three measures and later criminal status. In a separate study of 5,000 youths, Wadsworth (1976) also found a significant relation between low resting heart rate at age 11 and criminal acts by age 21 . Studies assessing arousal through measures of catecholamines (adrenaline or noradrenaline) or cortisol have shown similar relations between low arousal and aggression (Magnusson et al., Virkkunen, 1985).

One social-cognitive interpretation of this effect is that low-arousal individuals are less likely to experience negative affect during evaluation of aggressive scripts. Thus, they are more likely to use the script (Huesmann, 1997). An alternative possibility presumes an optimal arousal level for everyone. Low-arousal individuals may engage in more risky and sensation-producing kinds of behavior, including antisocial and aggressive acts, to increase their arousal. These two interpretations help to make sense of the phenomenon, described earlier, in which stimuli that increase arousal can produce increases in aggression. Individuals with low average levels of arousal may be more likely to seek arousing stimuli or situations that also tend to increase aggression, or they may be less likely to avoid such stimuli or situations.

Some individual differences in baseline arousal are innate, but it appears that learning also plays a role. Researchers have shown that people habituate to repeated exposure to scenes of violence, displaying less emotional reaction (Smith and Donnerstein, 1998). Lazarus et al. (1962) found that skinconductance responses decreased as the presentation of a violent film continued. Cline et al. (1973) reported that heavy TV viewers showed less skin conductance when they saw a violent film. Thomas 
et al. (1977) showed a similar effect for children. This desensitization process illustrates how a repeated environmental stimulus can act as a modifier of biological processes.

\section{Low serotonin}

Heightened aggressiveness is also related to low levels of the neurotransmitter serotonin (5-HT [5-hydroxytryptamine] or its metabolite 5-HIAA [5-hydroxyindoleacetic acid]). Studies of humans and animals (even invertebrates) have found changes in serotonin levels in individuals who engage in aggressive and violent behavior repeatedly (Miczek et al., 1994). For example, Linnoila and Virkkunen (Linnoila et al., 1983; Virkkunen and Narvanen, 1987; Virkkunen et a!., 1989a, 1989b) reported that violent offenders, impulsive criminals, and people who have attempted suicide all have lower levels of serotonin. In other studies of suicide, low serotonin has been shown to be correlated with number of suicide attempts, but not with depression (Oreland et al., 1981). Self-ratings of hostility (Rydin et al., 1982) and aggression (Coccaro, 1989; Brown et al., 1979) also correlate with depressed central nervous system (CNS) serotonin. In children, low serotonin has been found to correlate with reported behavior problems (Brown et al., 1985) and with conduct disorder (Stoff et al., 1987). Animal experimental data in which CNS serotonin is manipulated provide causal data consistent with these correlational data (Kantak et at., 1981)

Low serotonin appears to produce an inability to inhibit impulsive responses to provocation or aversive stimulation. For example, in the Linnoila et al. (1983) study, criminals convicted of impulsive violent crimes had lower serotonin than criminals with premeditated crimes. Soubrie (1986) proposed that the CNS serotonergic system's role is to inhibit active responses to external stimuli when passive responses are more appropriate.

\section{High testosterone}

Testosterone may affect aggression in two different ways. Over the long term, it can affect the development of various CNS and bodily structures (such as muscles and height) that change the likelihood and the success rate of aggression. This can be called the organizing effect. In the short run, it may also have an instigating effect on aggression. Though both effects are well established in animals (Book et al., 2002), only the organizing effect is supported by substantial evidence in humans.

Injection studies in animals demonstrate causal links between testosterone and developmental changes that promote aggression (see Brain, 1994, for a review). A few studies with humans in which pregnant woman have been treated with androgens provide causal support for such organizing effects in humans. For example, Reinisch (1981) found that children of mothers treated with progestin to prevent toxemia showed more propensity for physical aggression at about age 5 than did same-sex siblings who were born when the mother was not being treated.

In animals, the immediate instigating effect of testosterone on aggression has also been clearly demonstrated with injection studies and with observation that naturally occurring cyclical variations in testosterone correspond to variations in aggression (Brain, 1994). However, in humans, the presence of an instigating effect is much more problematic. One of the reasons is that there is also substantial evidence that various behavioral outcomes closely related to aggression affect circulating testosterone levels (Archer, 1988).

Two major meta-analyses (Archer, 1991; Book et al., 2002) have concluded that there is a weak but significant positive correlation (about 0.14) between current level of circulating testosterone and various measures of aggression in humans. Studies investigating whether testosterone levels in humans are affected by certain outcomes (such as dominance, winning, losing, and aggression) also tend to show weak positive effects, but with many exceptions. Laboratory studies of competitions such as reaction time tasks, video games, or coin tossing show that male winners usually experience an increase in testosterone (Gladue et al., 1989; Mazur et at., 1997; McCaul et al., 1992). Similar results have occurred in naturalistic studies of judo competitors (Salvador et al., 1987), wrestlers and tennis players (Elias, 1981), and chess players (Mazur et at., 1992). Even the fans of a winning team show increases in testosterone relative to fans of a losing team (Mazur and Booth, 1998).

Taken together, this research strongly suggests a reciprocal influence process for the short-term relation between testosterone and aggression. Higher levels of plasma testosterone probably increase aggression slightly, but the outcome of winning and dominating or losing probably affects testosterone levels just as much. Interestingly, Schaal et al. (1995) report that 12-year-old boys rated as being 'tough' and 'socially dominating' had the highest levels of testosterone - greater than 'nondominant' boys who scored even higher on aggression.

\section{Executive functioning deficits}

Although heightened aggressiveness has been linked to low IQ (Huesmann et al., 1987; Moffitt and Lynam, 1994; Wilson and Herrnstein, 1985), the reason is not clear. Moffitt and Lyman (1994) argued that a verbal IQ deficit makes it difficult for a child to develop appropriate social problemsolving skills. Pennington and Bennetto (1993) argued that deficits in frontal lobe executive functioning limit the ways social behaviors can be planned, evaluated, and controlled. Even the direction of the 
relationship is unclear. Early longitudinal analyses showed that low IQ predicted later delinquency and aggression (Moffitt et al., 1981; West and Farrington, 1973), but the only published sophisticated comparison of directionality showed that, at least after age 8, aggression influenced academic performance more than IQ affected aggression (Huesmann et al., 1987). Of course, it is likely that early IQ and executive-functioning deficits increase the risk of early aggression, which, in turn, interferes with later intellectual development.

\section{Attention-deficit hype,-activity disorder} (ADHD)

Early ADHD is strongly correlated with early aggression (Hinshaw, 1987). ADHD also predicts aggression in adolescence and young adulthood (Farrington et al., 1990; Magnusson, 1987; Moffitt, 1990; Satterfield et al., 1982). Hinshaw (1991; Hinshaw et al., 1992) has shown that pharmacological treatment of ADHD symptoms also lowers concurrent aggression, though it has little effect on long-term aggression.

\section{Genetic predispositions}

It is clear that a substantial number of individual neurophysiological factors are related to aggression. The extent to which these factors are influenced by heredity therefore becomes a relevant question. In animals, the heritability of aggression is well established (see Lagerspetz and Lagerspetz, 1971), and there is some evidence for humans as well. As Dick and Rose (2002: 70) succinctly conclude in their recent review, 'genetic variation contributes to individual differences in virtually all behavioral domains'. A substantial number of twin and adoption studies show some heritability of aggressive or antisocial tendencies (Coie and Dodge, 1998: 35; Miles and Carey, 1997). For example, in Tellegen et al's (1988) 'Minnesota' study of twins reared apart, correlations of aggression scores in adulthood were 0.64 for monozygotic twins and 0.34 for same-sexed dyzygotic (DZ) (MZ) twins. The Denmark studies of all twins born between 1880 and 1910 found that correlations with criminal registration were 0.74 for $\mathrm{MZ}$ twins and 0.46 for DZ twins (Christiansen, 1977; Cloninger and Gottesman, 1987). However, in their metaanalysis of 22 twin and adoption studies, Miles and Carey (1997) found two discrepant results. First, shared genetic variance accounted for up to 50 percent of the variance in self- or parent-reported aggression. Second, when aggressiveness was measured by careful observation of laboratory behaviors, the genetic effect disappeared, and a strong family environment effect emerged. Similarly, DiLalla and Gottesman (1991) pointed out that genetic effects are smaller when the criterion measure is prediction of actual behaviors. One must also remember that the likely neurophysiological mechanisms involved act as predisposes to higher risk, and that biosocial interactions are probably important.

\section{INTERVENTIONS}

For years, it seemed that interventions designed to reduce aggression in highly aggressive people were doomed to failure. Indeed, many of the most popular interventions currently in use have no validity, and some may increase aggression (Surgeon General, 2001).

Social-cognitive theories of aggression provide a plausible explanation for the fact that attempts to change overly aggressive individuals become increasingly less successful as these individuals become older. An admittedly oversimplified explanation is that with increasing life experiences one's typical construal of the social world is based on increasingly well-rehearsed and accessible knowledge structures, which are inherently difficult to change. Similarly, this approach accounts for the fact that narrowly based prevention or treatment programs tend not to work, presumably because there are so many ways that maladaptive knowledge structures can be learned and reinforced. Indeed, the most successful interventions are those that address multiple sources of potentially maladaptive learning environments, and do so at relatively young ages (e.g., Zigler et al., 1992).

Attempts to treat or rehabilitate violent adults, usually done in the context of prison programs, have led to a general consensus of failure. However, several studies of very time-intensive interventions have yielded some positive effects (e.g., Rice, 1997; Simon, 1998).

Many treatments have been tried with violent juvenile offenders, including such things as boot camps, individual therapy, scared-straight programs, and group therapy; there is little evidence of sustained success for these particular approaches. One problem is that these approaches do not address the wide range of factors that contribute to the development and maintenance of violent behavior. However, treatment can have a significant beneficial impact on violent juvenile offenders (e.g., Simon, 1998; Tate et al., 1995). One promising approach is multisystemic therapy (Borduin, 1999; Henggeler et al., 1998). This family-based approach identifies the major factors contributing to the delinquent and violent behaviors of the particular individual undergoing treatment. Biological, school, work, peer-group, family, and neighborhood factors are examined. Intervention is then tailored to fit the individual constellation of contributing factors. Opportunities to observe and commit further violent and criminal offenses are 
severely restricted, whereas prosocial behavior opportunities are enhanced and rewarded. The longterm success rate and the cost/benefit ratio of this approach have greatly exceeded other attempts at treating violent juveniles.

Attempts at primary prevention of aggression in youth through school-based interventions also generally yield disappointing results (Surgeon General, 2001) though some successes for social-cognitive interventions have been reported. A large-scale elementary-school-based preventive intervention in the Chicago area involving a social-cognitive curriculum, social-cognitive peer-group training, and a family intervention showed some success, but only for children living in communities that were not severely impoverished (Huesmann, 2000; Metropolitan Area Child Research Group, 2002). Another social-cognitive intervention (Conduct Problems Prevention Research Group, 1999) that followed a smaller set of high-risk children with repeated interventions, also reported some success in reducing aggression, but only in some contexts. More research on long-term effects of. social-cognitive primary-prevention interventions is needed before definitive conclusions can be reached on their value.

\section{CONCLUSIONS}

Social-cognitive approaches to understanding human aggression have been developing for over 30 years. Current models converge on a common set of theoretical assumptions, largely because those assumptions have proven useful in organizing the vast research literature and in generating new, testable hypotheses concerning the development, persistence, and change of aggression. The general aggression model is itself merely an attempt to unify these many strands into a common framework. It is possible to do so only because of the intensive theoretical work that has gone before, and because the underlying concepts have been so valuable regardless of the specific labels used.

An interesting trend that has emerged in the last decade or so concerns interventions. Gone are the days when aggression scholars had to admit that despite years of work there were no successful ones. The social-cognitive approach itself suggests why many popular approaches have failed, and why certain approaches work (Eton et al., 1994).

\section{NOTES}

1 Crick and Grotpeter (1995) have renamed (with minor changes) the indirect-aggression construct developed by Lagerspetz and Bjorkqvist (1992) as 'relational aggression'.
However, we prefer to use the original label which seems to reflect the kind of aggression more accurately.

2 Though Nisbett and Cohen (1996) present evidence that a culture of honor is positively related to violence, that finding cannot 'explain' the apparent hot-temperature effects on violence (Anderson, 2001; Anderson and Anderson, 1996; Anderson et al., 2000; Berkowitz, 2002).

3 A few longitudinal studies have seemed to produce results at odds with the thesis that media violence causes aggression, but closer inspection of these studies reveals that their results are not discrepant, but simply not strongly supportive of the thesis. (For a review, see Huesmann and Miller, 1994.) The most widely cited - NBC's longitudinal study of middle-childhood youth conducted in the 1970 s (Milavsky et al., 1982) - reported significant regression coefficients for only two of the 15 critical tests of the causal theory for boys; however, an additional ten were in the predicted direction. For girls, three of the 15 critical tests were significant and an additional seven were in the predicted direction. Furthermore, a number of the most aggressive children were dropped from the reported analyses, a fact which may have biased the results against finding significant media-violence effects.

REFERENCES

Anderson, C.A. (1989) 'Temperature and Aggression: Ubiquitous Effects of Heat on the Occurrence of Human Violence', Psychological Bulletin, 106: 74-96.

Anderson, C.A. (1997) 'Effects of Violent Movies and Trait Irritability on Hostile Feelings and Aggressive Thoughts', Aggressive Behavior, 23: 161-78.

Anderson, C.A. (2001) 'Heat and Violence', Current Directions in Psychological Science, 10: 33-8.

Anderson, C.A. (2002) 'Violent Video Games and Aggressive Thoughts, Feelings and Behaviors', in S.L. Calvert, A.B. Jordan and R.R. Cocking (eds), Children in the Digital Age. Wesport, CT: Praeger Publishers, pp. 101-19.

Anderson, C.A. and Anderson, K.B. (1996) 'Violent Crime Rate Studies in Philosophical Context: A Destructive Testing Approach to Heat and Southern Culture of Violence Effects', Journal of Personality and Social Psychology, 70: 740-56.

Anderson, C.A., Anderson, K.B. and Denser, W.E. (1996) 'Examining an Affective Aggression Framework: Weapon and Temperature Effects on Aggressive Thoughts, Affect and Attitudes', Personality and Social Psychology Bulletin, 22: 366-76.

Anderson, C.A., Anderson, K.B., Doff, N., Deneve, K.M. and Flanagan, M. (2000) 'Temperature and Aggression', in M. Zanna (ed.), Advances in Experimental Social Psychology (vol. 32). New York: Academic Press. 63-133.

Anderson, C.A., Benjamin, A.J. and Bartholow, B.D. (1998) 'Does the Gun Pull the Trigger? Automatic Priming Effects of Weapon Pictures and Weapon Names', Psychological Science, 9: 308-14. 
Anderson, C.A., Benjamin, A.J., Wood, P.K., and Bonaccj, A.M. (under review) 'Development and Testing of the Attitudes Toward Violence Scale: Evidence for a Four-Factor Model',

Anderson, C.A. and Bushman, B.J. (2001) 'Effects of Violent Video Games on Aggressive Behavior, Aggressive Cognition, Aggressive Affect, Physiological Arousal and Prosocial Behavior: A Meta-analytic Review of the Scientific Literature', Psychological Science, 12: 353-9.

Anderson, C.A. and Bushman, B.J. (2002a) 'Human Aggression', Annual Review of Psychology, 53: 27-51.

Anderson, C.A. and Bushman, B.J. (2002b) 'The Effects of Media Violence on Society', Science, 295: 2377-8.

Anderson, C.A., Bushman, B.J., and Groom, R.W. (1997) 'Hot Years and Serious and Deadly Assault: Empirical Tests of the Heat Hypothesis', Journal of Personality and Social Psychology, 16: 1213-23.

Anderson, C.A. and Dill, K.E. (2000) 'Video Games and Aggressive Thoughts, Feelings and Behavior in the Laboratory and in Life', Journal of Personality and Social Psychology, 78: 772-90.

Anderson, K.L. (1990) 'Arousal and the Inverted-U Hypothesis: A Critique of Neiss's "Reconceptualizing Arousal"', Psychological Bulletin, 107: 96-100.

Anderson, K.B. (1996) 'Cognitive and Personality Predictors of Male-on-Female Aggression: An Integration of Theoretical Perspectives'. Unpublished dissertation, Columbia, MO.

Anderson, K.B., Anderson, C.A., Dill, K.E., and Denser, W.E. (1998) 'The Interactive Relations Between Trait Hostility, Pain and Aggressive Thoughts', Aggressive Behavior, 24: 161-71.

Archer, J. (1988) The Behavioral Biology of Aggression. Cambridge: Cambridge University Press.

Archer, J. (1991) 'The Influence of Testosterone on Human Aggression', British Journal of Psychology, 82: 1-28.

Archer, J. (2000) 'Sex Differences in Aggression Between Heterosexual Partners: A Mets-Analytic Review', Psychological Bulletin, 126: 697-702.

Azar, S.T. and Rohrbeck, C.A. (1986) 'Child Abuse and Unrealistic Expectations: Further Validation of the Parent Opinion Questionnaire', Journal of Consulting and Clinical Psychology, 54: 867-8.

Bandura, A. (1973) Aggression: A Social Learning Theory Analysis. Englewood Cliffs, NJ: Prentice-Hall.

Bandura, A. (1977) Social Learning Theory. New York: Prentice-Hall.

Bandura, A. (1983) 'Psychological Mechanism of Aggression', in R.G. Geen and E.1. Donnerstein (eds), Aggression: Theoretical and Empirical Reviews (vol. 1). New York: Academic Press. pp. 1-40.

Bandura, A. (1986) Social Foundations of Thought and Action: A Social-Cognitive Theory. Englewood Cliffs, NJ: Prentice-Hall.

Bandura, A., Barbaranelli, C., Caprara, G.V., and Pastorelli, C. (1996) 'Mechanisms of Moral Disengagement in the Exercise of Moral Agency',
Journal of Personality and Social Psychology, 71: 364-74.

Bargh, J.A., (1989) 'Conditional Automaticity: Varieties of Automatic Influence in Social Perception and Cognition', in J.S. Uleman and J.A. Bargh (eds), Unintended Thought. New York: Guilford Press.

Bargh, J.A., Chen, M., and Burrows, L. (1996) 'Automaticity of Social Behavior: Direct Effects of Trait Construct and Stereotype Priming on Action', Journal of Personality and Social Psychology, 71: 230-44.

Bargh, J.A., Raymond, P., Pryor, J., and Strack, F. (1995) 'Attractiveness of the Underling: An Automatic Power-Sex Association and its Consequences for Sexual Harassment and Aggression', Journal of Personality and Social Psychology, 68: 768-81.

Bargh, J.A. and Pietromonaco, P. (1982) 'Automatic Information Processing and Social Perception: The Influence of Trait Information Presented Outside of Conscious Awareness on Impression Formation', Journal of Personality and Social Psychology, 43: 43 7-49.

Baron, R. (1977) Human Aggression. New York: Plenum.

Baron, R.A. and Richardson, D.R. (1994) Human Aggression, 2nd edn. New York: Plenum Press.

Bartholow, B.D., Anderson, C.A., Benjamin, A.J., and Carnagey, N.L. (under review) Individual Differences in Knowledge Structures and Priming: The Weapons Priming Effect in Hunters and Nonhunters.

Baumeister, R.F. and Boden, J.M. (1998) 'Aggression and the Self: High Self-esteem, Low Self-Control and Ego Threat', in R. Geen and E. Donnerstein (eds), Human Aggression: Theories. Research and Implications for Policy. New York: Academic Press. pp. 111-37.

Baumeister, R.F., Smart, L., and Boden, J.M. (1996) 'Relation of Threatened Egotism to Violence and Aggression: The Dark Side of High Self-Esteem', Psychological Review, 103: 5-33.

Berkowitz, L. (1982) 'Aversive Conditions as Stimuli to Aggression', in L. Berkowitz (ed.), Advances in Experimental Social Psychology (vol. 15). New York: Academic Press. pp. 249-88.

Berkowitz, L. (1989) 'Frustration-Aggression Hypothesis: Examination and Reformulation', Psychological Bulletin, 106: 59-73.

Berkowitz, L. (1993) Aggression: Its Causes, Consequences and Control. New York: Mcgraw-Hill.

Berkowitz, L. (in press) 'Affect, Aggression and Antisocial Behavior', in R. Davidson, K. Scherer, and H. Goldsmith (eds), Handbook of Affective Sciences, New York: Oxford University Press.

Berkowitz, L. and Donnerstein, E. (1982) 'External Validity Is More Than Skin Deep: Some Answers to Criticism of Laboratory Experiments', American Psychologist, 37: 245-57.

Berkowitz, L., Cochran, S.T., and Embree, M.C. (1981) 'Physical Pain and the Goal of Aversively Stimulated Aggression', Journal of Personality and Social Psychology, 40: 687-700.

Berkowitz, L. and LePage, A. (1967) 'Weapons as Aggression-Eliciting Stimuli', Journal of Personality and Social Psychology, 7: 202-7. 
Berkowitz, L. and Troccoli, B.T. (1990) 'Feelings, Direction of Attention and Expressed Evaluations of Others', Cognition and Emotion, 4: 305-25.

Bettencourt, B.A. and Kernahan, C. (1997) 'A MetaAnalysis of Aggression in the Presence of Violent Cues: Effects of Gender Differences and Aversive Provocation', Aggressive Behavior, 23: 447-56.

Bettencourt, B.A. and Miller, N. (1996) 'Gender Differences in Aggression as a Function of Provocation: A Meta-Analysis', Psychological Bulletin, 119: 422-47.

Bjorkqvist, K., Lagerspetz, K., and Kaukiainen, A. (1992) 'Do Girls Manipulate and Boys Fight? Developmental Trends in Regard to Direct and Indirect Aggression', Aggressive Behavior, 18: 117-27.

Book, A.S., Starzyk, K.B., and Quinsey, V.L. (2002) 'The Relationship Between Testosterone and Aggression: A Meta-Analysis', Aggression and Violent Behavior, 6: 579-99.

Bookwala, J., Frieze, I., Smith, C., and Ryan, K. (1992) 'Predictors of Dating Violence: A Multivariate Analysis', Violence and Victims, 7: 297-311.

Borduin, C.M. (1999) 'Multisystemic Treatment of Criminality and Violence in Adolescents', Journal of the American Academy of Child and Adolescent Psychiatry, 38: 242-9.

Brain, P.F. (1986) 'Multidisciplinary Examinations of the "Causes" of Crime: The Case of the Link Between Alcohol and Violence', Alcohol and Alcoholism, 21: 237-40.

Brain, P.F. (1994) 'Hormonal Aspects of Aggression and Violence', in A.J. Reis, Jr. and J.A. Roth (eds), Understanding and Control of Biobehavioral Influences on Violence (vol. 2). Washington, DC: National Academy Press. pp. 177-244.

Brame, B., Nagin, D.S., and Tremblay, R.E. (2001) 'Developmental Trajectories of Physical Aggression from School Entry to Late Adolescence', Journal of Child Psychology and Psychiatry, 42 (4): 503-12.

Broadbent, D.E. (1971) Decision and Stress. London: Academic Press.

Brown, G.L., Goodwin, F.K., Ballenger, J.C., Goyer, P.F., and Major, L.F. (1979) 'Aggression in Humans Correlates with Cerebrospinal Fluid Amine Metabolites', Psychiatry Research, 1: 131-9.

Brown, G.L., Klein, W.J., Goyer, P.F., et al. (1985) 'Relationship of Childhood Characteristics of CSF 5-HIAA in Aggressive Adults', presented at Fourth World Congress of Biological Psychiatry (Abstract 216.3), Philadelphia, PA.

Bushman, B.J. (1993) 'Human Aggression While Under the Influence of Alcohol and Other Drugs: An Integrative Research Review', Current Directions in Psychological Science, 2, 148-52.

Bushman, B.J. (1997) 'Effects of Alcohol on Human Aggression: Validity of Proposed Explanations', in D. Fuller, R. Dietrich, and E. Gottheil (eds), Recent Developments in Alcoholism: Alcohol and Violence (vol. 13). New York: Plenum. pp. 227-43.

Bushman, B.J. (1998) 'Priming Effects of Violent Media on the Accessibility of Aggressive Constructs in
Memory', Personality and Social Psychology Bulletin. 24: $537-45$.

Bushman, B.J. and Anderson, C.A. (2001) 'Is It Time to Pull the Plug on the Hostile Versus Instrumental Aggression Dichotomy?', Psychological Review, 108: 273-9.

Bushman, B.J. and Baumeister, R.F. (1998) 'Threatened Egotism, Narcissism, Self-Esteem and Direct and Displaced Aggression: Does Self-Love or Self-Hate Lead to Violence?', Journal of Personality and Social Psychology, 75: 219-29.

Bushman, B.J. and Huesmann, L.R. (2000) 'Effects of Televised Violence on Aggression', in D. Singer and J. Singer (eds), Handbook of Children and the Media. Thousand Oaks, CA: Sage. pp. 223-54.

Buss, A.H. and Perry, M.P. (1992) 'The Aggression Questionnaire', Journal of Personality and Social Psychology, 63: 452-9.

Buss, D.M. and Shackelford, T.K. (1997a) 'From Vigilance to Violence: Mate Retention Tactics in Married Couples', Journal of Personality and Social Psychology, 72: 346-61.

Buss, D.M. and Shackelford, T.K. (1997b) 'Human Aggression in Evolutionary Psychological Perspective', Clinical Psychology Review, 17: 605-19.

Cairns, R.B. and Cairns, B.D. (1994) Lifelines and Risks. Pathways of Youth in Our lime. New York: Cambridge University Press.

Campbell, A. (1999) 'Staying Alive: Evolution, Culture and Women's Intrasexual Aggression', Behavioral and Brain Sciences, 22: 203-52.

Caplan, M., Vespo, J., Pedersen, J., and Hay, D.F. (1991) 'Conflict over Resources in Small Groups of One- and Two-Year-Olds', Child Development, 62: 1513-24.

Caprara, G.V., Barbaranelli, C., Pastorelli, C., and Perugini, M. (1994) 'Individual Differences in the Study of Aggression', Aggressive Behavior, 20: 291-303.

Caprara, G.V., Cinanni, B., D'Imperio, G., Passerini, S., Renzi, P., and Travaglia, G. (1985) 'Indicators of Impulsive Aggression: Present Status of Research on Irritability and Emotional Susceptibility Scales', Personality and Individual Differences, 6: 665-74

Carison, M., Marcus-Newhall, A., and Miller, N. (1990) 'Effects of Situational Aggression Cues: A Quantitative Review', Journal of Personality and Social Psychology, 58: 622-33.

Carver, C.S. (1974) 'Facilitation of Physical Aggression Through Objective Self-Awareness', Journal of Experimental Social Psychology, 10: 365-70.

Carver, C., Ganellen, R., Froming, W., and Chambers, W. (1983) 'Modeling: An Analysis in Terms of Category Accessibility', Journal of Experimental Social Psychology, 19: 403-21.

Chen, M. and Bargh, J.A. (1997) 'Nonconscious Behavioral Confirmation Processes: The Self-Fulfilling Consequences of Automatic Stereotype Activation', Journal of Experimental Social Psychology, 33: 541-60.

Christiansen, K. (1977) 'A Preliminary Study of Criminality Among Twins', in S.A. Mednick and 
K.O. Christiansen (eds), Biosocial Bases of Criminal Behavior. New York: Gardner Press. pp. 89-108.

Cline, V.B., Croft, R.G., and Courtier, S. (1973) 'Desensitization of Children to Television Violence', Journal of Personality and Social Psychology, 27: 360-5.

Cloninger, C.R. and Gottesman, 1.1. (1987) 'Genetic and Environmental Factors in Antisocial Behavior Disorders', in S.A. Mednick, T.E. Moffitt, and S. Stack (eds), The Causes of Crime: New Biological Approaches. Cambridge: Cambridge University Press.

Coccaro, E.G. (1989) 'Central Serotonin and Impulsive Aggression', British Journal of Psychiatry, 155: 52-62. Coie, J. and Dodge, K. (1998) 'Aggression and Antisocial Behavior', in W. Damon and N. Eisenberg (eds), Handbook of Child Psychology. New York: Wiley. pp. 779-862.

Conduct Problems Prevention Research Group (1999) 'Initial Impact of the Fast Track Prevention Trial for Conduct Problems. I. The High Risk Sample', Journal of Consulting and Clinical Psychology, 67: 631-47.

Crick, N.R. and Dodge, K.A. (1994) 'A Review and Reformulation of Social Information Processing Mechanisms in Children's Adjustment', Psychological Bulletin, 115: 74-101.

Crick, N.R. and Grotpeter, J.K. (1995) 'Relational Aggression, Gender and Social-Psychological Adjustment', Child Development, 66: 7 10-22.

Daly, M. and Wilson, M. (1994) 'Evolutionary Psychology of Male Violence', in J. Archer (ed.), Male Violence. London: Routledge. pp. 253-88.

Deluty, RH. (1981) 'Alternative Thinking Ability of Aggressive, Assertive and Submissive Children', Cognitive Therapy and Research, 5: 309-12.

Devine, P.G. (1989) 'Stereotypes and Prejudice: Their Automatic and Controlled Components', Journal of Personality and Social Psychology, 56: 680-90.

Dick, D.M. and Rose, R.J. (2002) 'Behavior Genetics: What's New? What's Next?', Current Directions in Psychological Science, 11(2): 70-4.

Diener, E. (1976) 'Effects of Prior Destructive Behavior, Anonymity and Group Presence on Deindividuation and Aggression', Journal of Personality and Social Psychology, 33: 497-507.

Dilalla, L.F. and Gottesman, 1.1. (1991) 'Biological and Genetic Contributors to Violence: Widom's Untold Tale', Psychological Bulletin, 109: 125-29.

Dill, J. and Anderson, C.A. (1995) 'Effects of Justified and Unjustified Frustration on Aggression', Aggressive Behavior, 21: 359-69.

Dill, K.E., Anderson, C.A., Anderson, K.B., and Denser, W.E. (1997) 'Effects of Aggressive Personality on Social Expectations and Social Perceptions', Journal of Research in Personality, 31: 272-92.

Dodge, K.A. (1980) 'Social Cognition and Children's Aggressive Behavior', Child Development, 51: 620-3 5. Dodge, K.A. (1986) 'A Social Information Processing Model of Social Competence in Children', in M. Perlmutter (ed.), The Minnesota Symposium on Child Psychology (vol. 18). Hillsdale, NJ: Erlbaum. pp. 77-125.
Dodge, K.A. and Coie, J.D. (1987) 'Social InformationProcessing Factors in Reactive and Proactive Aggression in Children's Peer Groups', Journal of Personality and Social Psychology, 53: 1146-58.

Dodge, K.A. and Frame, C.L. (1982) 'Social Cognitive Biases and Deficits in Aggressive Boys', Child Development, 53: 620-35.

Dodge, K.A., Price, J.M., Bachorowski, J.A., and Newman, J.P. (1990) 'Hostile Attributional Biases in Severely Aggressive Adolescents', Journal of Abnormal Psychology, 99: 385-92.

Dodge, K.A. and Tomlin, A. (1987) 'Utilization of Self-Schemas as a Mechanism of Attributional Bias in Aggressive Children', Social Cognition, 5 (3): pp. 280-300.

Dollard, J., Doob, L.W., Miller, N.E., Mower, O.H., and Sears, R.R. (1939) Frustration and Aggression. New Haven, CT: Yale University Press.

Earls, F. (1980) 'The Prevalence of Behavior Problems in 3-Year-Old Children', Archives of General Psychiatry, 37: 1153-9.

Easterbrook, J.A. (1959) 'The Effect of Emotion on Cue Utilization and the Organization of Behavior', Psychological Review, 66: 183-201.

Ekman, P. and Friesen, W.V. (1975) Unmasking The Face: A Guide to Recognizing Emotions from Facial Clues. New York: Prentice-Hall.

Elias, M. (1981) 'Serum Cortisol, Testosterone and Testosterone-Binding Globulin Responses to Competitive Fighting in Human Males', Aggressive Behavior, 7: 215-24.

Eton, L.D., Walder, L.O., and Lefkowitz, M.M. (1971) The Learning of Aggression in Children. Boston, MA: Little Brown.

Eron, L.D., Gentry, J.H., and Schiegel, P. (1994) Reason to Hope: A Psychosocial Perspective on Violence and Youth. Washington, DC: American Psychological Association.

Eton, L.D., Huesmann, L.R., Lefkowitz, M.M., and Walder, L.O. (1972) 'Does T.V. Violence Cause Aggression?', American Psychologist, 27: 153-263.

Farrington, D.P. (1982) 'Longitudinal Analyses of Criminal Violence', in M.E. Wolfgang and N.A. Weiner (eds), Criminal Violence. Beverly Hills, CA: Sage. pp. 171-200.

Farrington, D.P. (1993) 'Motivations for Conduct Disorder and Delinquency', Development and Psychopathology, 5: 225-41.

Farnngton, D.P. (1995) 'The Development of offending and Antisocial Behavior from Childhood: Key Findings from the Cambridge Study in Delinquent Development', Journal of Child Psychology and Psychiatry, 36: 1-36.

Farrington, D.P. (1999) Crime and Justice in the United States and in England and Wales, 1981-1996. US Department of Justice, Bureau of Justice Statistics.

Farrington, D.P. (2002) 'Multiple Risk Factors for Multiple Problem Violent Boys', in R. Corrado et al. (eds), Multi-Problem Violent Youth: A Foundation for Comparative Research on Needs Interventions and Outcomes. Series 1 Life and Behavioural Sciences, vol. 324. Netherlands: 1OS Press. pp. 23-34. 
Farrington, D.P., Loeber, R., and Van Kammen, W.B. (1990) 'Long-Term Criminal Outcomes Of Hyperactivity-Impulsivity-Attention Deficit and Conduct Problems in Childhood', in L.N. Robins and M. Rutter (eds), Straight and Devious Pathways from Childhood to Adulthood. Cambridge: Cambridge University Press. pp. 62-81.

Feshbach, S. (1964) 'The Function of Aggression and the Regulation of Aggressive Drive', Psychological Review, 71: $257-72$.

Fiske, S.T. (1982) 'Schema-Triggered Affect: Applications to Social Perception', in M.S. Clark and S.T. Fiske (eds), Affect and Cognition: The 17th Annual Carnegie Symposium on Cognition. Hillsdale, NJ Erlbaum. pp. 55-78.

Fiske, ST. and Taylor, S.E. (1991) Social Cognition. New York: Mcgraw-Hill

Fraczek, A. (1985) 'Moral Approval of Aggressive Acts: A Polish-Finnish Comparative Study', Journal of Cross-Cultural Psychology, 16: 41-51.

Fujihara, T., Kohyama, T., Andreu, J.M., and Ramirez, M.J. (1999) 'Justification of Interpersonal Aggression in Japanese, American and Spanish Students', Aggressive Behaviour, 25 (3): 185-95.

Geary, D.C. (1998) Male, Female: The Evolution of Human Sex Differences. Washington, DC: American Psychological Association.

Geary, D.C., Rumsey, M., Bow-Thomas, C.C., and Hoard, M.K. (1995) 'Sexual Jealousy as a Facultative Trait: Evidence from the Pattern of Sex Differences in Adults from China and the United States', Ethology and Sociobiology, 16: 355-83.

Geen, R.G. (1968) 'Effects of Frustration, Attack and Prior Training in Aggressiveness upon Aggressive Behavior', Journal of Personality and Social Psychology, 27: $389-95$

Geen, R.G. (2001) Human Aggression. Philadelphia, PA: Open University Press.

Geen, R.G. and O'Neal, E.C. (1969) 'Activation of Cue-Elicited Aggression By General Arousal', Journa of Personality and Social Psychology, 11: 2 89-92.

Gladue, B.A., Boechler, M., and McCaul, K.D. (1989) 'Hormonal Responses to Competition in Human Males', Aggressive Behavior, 17: 313-26.

Goldstein, A.P. (1994) 'Delinquent Gangs', in L.R. Huesmann (ed.), Aggressive Behavior: Current Perspectives. Plenum Series in Social/Clinical Psychology. New York: Plenum Press. pp. 255-73.

Gouse, K.R. (1981) 'Attention and Social Problem Solving as Correlates of Aggression in Preschool Males', Journal of Abnormal Child Psychology, 15: 181-97.

Graham, S. and Hudley, C. (1994) 'Attributions of Aggressive and Nonaggressive African-American Male Early Adolescents: A Study of Construct Accessibility', Developmental Psychology, 30: 365-73.

Greeson, L.E. and Williams, R.A. (1986) 'Social Implications of Music Videos for Youth: An Analysis of the Content and Effects of MTV', Youth and Society, 18: $177-89$
Griffitt, W. (1970) 'Environmental Effects on interpersonal Affective Behavior: Ambient Effective Temperature and Attraction', Journal of Personality and Social Psychology, 15: 240-4

Guerra, N.G., Huesmann, L.R., and Spindler, A.J. (2002) Community Violence Exposure, Social Cognition and Aggression Among Urban Elementary-School Children. Institute for Social Research, University of Michigan.

Guerra, N.G., Huesmann, L.R., Tolan, P., Van Acker, R., and Eron, L.D. (1995) 'Stressful Events and Individual Beliefs as Correlates of Economic Disadvantage and Aggression Among Urban Children', Journal of Consulting and Clinical Psychology, 63 (4): 518-28.

Hansen, C.H. and Hansen, R.D. (1989) 'The Content of MTS's Daily Countdown: "Dial MTV" for Sex, Violence and Antisocial Behavior'. Unpublished manuscript.

Hansen, C.H. and Hansen, R.D. (1990) 'Rock Music Videos and Antisocial Behavior', Basic and Applied Social Psychology, 11: 357-69.

Hare, R.D. (1978) 'Electrodermal and Cardiovascular Correlates of Psychopathy', in R.D. Hare and D. Schalling (eds), Psychopathic Behavior: Approaches to Research. New York: Wiley. pp. 107-44.

Henggeler, SW., Schoenwald, S.K., Borduin, C.M., Rowland, M.D., and Cunningham, P.B. (1998) Multisystemic Treatment of Antisocial Behavior in Children and Adolescents. New York: Guilford.

Henry, D., Guerra, N., Huesmann, R., and Van Acker, R. (1996) 'Normative Influences on Aggression in Urban Elementary School Classrooms'. Manuscript submitted for publication.

Hinshaw, S.P. (1987) 'On the Distinction Between Attentional Deficits/Hyperactivity and Conduct Problems/Aggression in Child Psychopathology', Psychological Bulletin, 101: 443-63.

Hinshaw, S.P. (1991) 'Stimulant Medication and the Treatment of Aggression in Children with Attentional Deficits', Journal of Clinical Child Psychology, 20: 301-12.

Hinshaw, S.P., Heller, 1., and Mchale, J.P. (1992) 'Covert Antisocial Behavior in Boys with Attention-Deficit Hyperactivity Disorder: External Validation and Effects of Methylphenidate', Journal of Consulting and Clinical Psychology, 60: 274-81.

Horowitz, R. and Schwartz, G. (1974) 'Honor, Normative Ambiguity and Gang Violence', American Sociological Review, 39: 238-51.

Howard, R.C. (1984) 'The Clinical EEG and Personality in Mentally Abnormal Offenders', Psychological Medicine, 14: $569-80$.

Huesmann, L.R. (1982) 'Information Processing Models of Behavior', in N. Hirschberg and L. Humphreys (eds), Multivariate Applications in the Social Sciences. Hillsdale, NJ: Erlbaum. pp. 261-88.

Huesmann, L.R. (1986) 'Psychological Processes Promoting the Relation Between Exposure to Media Violence and Aggressive Behavior by the Viewer', Journal of Social Issues, 42 (3): 125-39.

Huesmann, L.R. (1988) 'An Information Processing Model for the Development of Aggression', Aggressive Behavior. 14: 13-24. 
Huesmann, L.R. (1995) 'Early Prediction and Prevention of Aggression and Antisocial Behavior', Aggressive Behavior, 21(3): 190

Huesmann, L.R. (1997) 'Observational Learning of Violent Behavior: Social and Biosocial Processes', in A. Raine, D.P. Farnngton, P.O. Brennen, and S.A. Mednick (eds), The Biosocial Basis of Violence. New York: Plenum. pp. 69-88.

Huesmann, L.R. (1998) 'The Role of Social Information Processing and Cognitive Schemas in the Acquisition and Maintenance of Habitual Aggressive Behavior', in R.G. Geen and E. Donnerstein (eds), Human Aggression: Theories, Research and Implications for Policy. New York: Academic Press. 73-109.

Huesmann, L.R. (2000) 'Analysis of Cognitive-Ecological Program for The Prevention of Violence in Inner-City Youth'. Paper presented at the meetings of The International Society for Research on Aggression, Valencia, Spain.

Huesmann, L.R. and Eton, L.D. (eds) (1986) Television and the Aggressive Child: A Cross-National Comparison. Hilisdale, N.J: Erlbaum.

Huesmann, L.R., Eton, L.D., Lefkowitz, M.M., and Walder, L.O. (1984a) 'Stability of Aggression over Time and Generations', Developmental Psychology, 20:1120-34

Huesmann, L.R., Eron, L.D., and Yarmel, P.W. (1987) 'Intellectual Functioning and Aggression', Journal of Personality and Social Psychology, 52: 232-40.

Huesmann, L.R. and Guerra, N.G. (1997) 'Children's Normative Beliefs About Aggression and Aggressive Behavior', Journal of Personality and Social Psychology, 72: 408-19.

Huesmann, L.R., Lagerspetz, K., and Eton, L.D. (1984b) Intervening Variables in the Television Violence -Aggression Relation: Evidence from Two Countries', Developmental Psychology, 20 (5): 746-75.

Huesmann, L.R. and Miller, L.S. (1994) 'Long-Term Effects of Repeated Exposure to Media Violence in Childhood', in L.R. Huesmann (ed.), Aggressive Behavior: Current Perspectives. New York: Plenum pp. 153-86.

Huesmann, L.R. and Moise, J. (1998) 'The Stability and Continuity of Aggression from Early Childhood to Young Adulthood', in D.J. Flannery and C.R. Huff (eds), Youth Violence: Prevention, Intervention, and Social Policy, Washington, DC: American Psychiatric Press. pp. 73-95.

Huesmann, L.R. and Moise-Titus, J. (2002) 'Normative Beliefs, Hostile Schemas and Script Rehearsal as Mediators of the Relation Between Childhood Observation of Violence and Adult Aggressive Behavior'. Paper presented at the meetings of the European Society for Social Psychology, San Sebastian, Spain, June.

Huesmann, L.R., Moise J., Podolski, C.P., and Eron, L.D. (in press) 'Longitudinal Relations between Children's Exposure to Television Violence and Their Aggressive and Violent Behaviour in Young Adulthood', Developmental Psychology, 1977-92.
Hyman, I. A. (1995) 'Corporal Punishment, Psychological Maltreatment, Violence and Punitiveness in America: Research, Advocacy and Public Policy', Applied and Preventive Psychology, 4: 113-30.

Johnson, J.G., Cohen, P., Smailes, E.M., Kasen, S., and Brook, J.S. (2002) 'Television Viewing and Aggressive Behavior During Adolescence and Adulthood', Science, 295: 2468-71.

Johnson, J., Jackson, L., and Gatto, L. (1995) 'Violent Attitudes and Deferred Academic Aspirations: Deleterious Effects of Exposure to Rap Music', Basic and Applied Social Psychology, 16: 279-94.

Jones, J. and Bogat, G. (1978) 'Air Pollution and Human Aggression'; Psychological Reports, 43: 721-2.

Kantak, K.M., Hegstrand, L.R., Eichelman, B. (1981) Facilitation of Shock-Induced Fighting Following Intraventricular 5, 7-Dehydroxytryptamine and 6-Hydroxydopa', Psychopharmacology, 74: 157-60.

Keltner, D. and Robinson, R.J. (1996) 'Extremism, Power and the Imagined Basis of Social Conflict', Current Directions in Psychological Science, 5: 101-5.

Kernis, M.H., Grannemann, B.D., and Barclay, L.C. (1989) 'Stability and Level of Self-Esteem as Predictors of Anger Arousal and Hostility', Journal of Personality and Social Psychology, 56: 1013-22.

Kingery, P.M. (1998) 'The Adolescent Violence Survey: A Psychometric Analysis', School Psychology International, 19: 43-59.

Klein, M.W. and Maxson, C.K. (1989) 'Street Gang Violence', in N. Weiner and M. Wolfgang (eds), Violent Crime, Violent Criminals. Newbury Park, CA Sage. pp. 198-234.

Lagerspetz, K.M. and Bjorkqvist, K. (1992) 'Indirect Aggression in Girls and Boys', in L.R. Huesmann (ed.), Aggressive Behavior: Current Perspectives. New York: Plenum. pp. 131-50.

Lagerspetz, K.M., Bjorkqvist, K., and Peltonen, T. (1988) 'Is Indirect Aggression Typical of Females? Gender Differences in Aggressiveness in 11- to 12-Year-Old Children', Aggressive Behavior, 14: 403-14.

Lagerspetz, K. and Lagerspetz, K.M.J. (1971) 'Changes in Aggressiveness of Mice Resulting from Selective Breeding, Learning and Social Isolation', Scandinavian Journal of Psychology, 12: 241-78.

Landau, S.F. (1988) 'Violent Crime and Its Relation to Subjective Social Stress Indicators: The Case of Israel', Aggressive Behavior, 13: 67-85.

Lang, AR, Goeckner, D.J., Adesso, V.J., and Marlatt, GA (1975) 'Effects of Alcohol on Aggression in Male Social Drinkers', Journal of Abnormal Psychology, 84 508-18.

Lazarus, R.S., Speisman, J.C., Mordkoff, AM., and Davidson, L.A. (1962) 'A Laboratory Study of Psychological Stress Produced by a Motion Picture Film', Psychological Monographs: General and Applied, 76 (34).

Lee, S., Huesmann, L.R., Crocker, J. (2002) Contingencies of Self-Worth and Aggressive Behavior'. Paper presented at the American Psychological Society, June. 
Lefkowitz, M.M., Eron, L.D., Walder, L.O., and Huesmann, L.R. (1977) Growing Up to Be Violent: A Longitudinal Study of the Development of Aggression. New York: Pergamon.

Leyens, J.P. and Fraczek, A. (1983) 'Aggression as an Interpersonal Phenomenon', in $\mathrm{H}$. Tajfel (ed.), The Social Dimension, (vol. 1). Cambridge: Cambridge University Press. p. 192.

Linnolia, M., Virkkunen, M., Scheinin, M., Nuutila, A., Rimon, R., and Goodwin, F.K. (1983) 'Low Cerebrospinal Fluid 5-Hydroxyindoleacetic Acid Concentration Differentiates Impulsive from Nonimpulsive Violent Behaviour', Life Science, 33: 2609-614.

Loeber, R. and Dishion, T.J. (1983) 'Early Predictors of Male Delinquency: A Review', Psychological Bulletin, 94: 68-94.

Loeber, R. and Hay, D.F. (1993) 'Developmental Approaches to Aggression and Conduct Problems', in M. Rutter and D.F. Hay (eds), Development Through Life: A Handbook for Clinicians. Oxford: Blackwell Scientific. pp. 488-516.

Loeber, R. and Hay, D. (1997) 'Key Issues in the Development of Aggression from Childhood to Early Adulthood', Annual Review of Psychology, 48: 371-410. Luria, A.R. (1973) The Working Brain. London: Penguin.

Magnusson, D. (1987) 'Adult Delinquency and Early Conduct and Physiology', in D. Magnusson and A. Ohman (eds), Psychopathology: An International Perspective. New York: Academic Press. pp. 221-34

Magnusson, D., Duner, A., and Zetterblom, G. (1975) Adjustment: A Longitudinal Study. Stockholm: Almqvist \& Wiksell.

Magnusson, D., Klinteberg, B., and Stattin, H. (1994) 'Juvenile and Persistent offenders: Behavioral and Physiological Characteristics', in R.D. Ketterlinus (ed.), Adolescent Problem Behaviors: Issues and Research. Hillsdale,NJ: Erlbaum. pp. 81-91.

Maguire, K. and Pastore, A.L. (eds) (2001) Sourcebook of Criminal Justice Statistics [online]. http://www.albany.edu/sourcebook/ [3/1/2002].

Malamuth, N.M. and Heilmann, M.F. (1998) 'Evolutionary Psychology and Sexual Aggression', in C.H. Crawford and D.L. Krebs (eds), Handbook of Evolutionary Psychology. Mahwah, NJ: Erlbaum. pp. 515-42.

Malamuth, N.M., Linz, D., Heavey, C.L., Barnes, G., and Acker, M. (1995) 'Using the Confluence Model of Sexual Aggression to Predict Men's Conflict with Women: a 10-Year Follow-Up Study', Journal of Personality and Social Psychology, 69: 3 53-69.

Marcus-Newhall, A., Pedersen, W.C., Carlson, M., and Miller, N. (2000) 'Displaced Aggression is Alive and Well: A Meta-Analytic Review', Journal of Personality and Social Psychology, 78: 670-89.

Markowitz, F.E. (2001) 'Attitudes and Family Violence: Linking Intergenerational and Cultural Theories', Journal of Family Violence, 16: 205-18.

Mazur, A. and Booth, A. (1998) 'Testosterone and Dominance in Men', Behavioral and Brain Sciences, 21: 353-97.
Mazur, A., Booth, A., and Dabbs Jr., J.M. (1992) 'Testosterone and Chess Competition', Social Psychology Quarterly, 55 (1): 70-7.

Mazur, A., Susman, E.J., and Edelbrock, S. (1997) 'Sex Differences in Testosterone Response to a Video Game Contest', Evolution and Human Behavior, 18: 317-26.

McCaul, K.D., Gladue, B.A., and Joppa, M. (1992) 'Winning, Losing, Mood and Testosterone', Hormones and Behavior, 26: 486-504.

Mcfall, R.M. (1982) 'A Review and Reformulation of the Concept of Social Skills', Behavioral Assessment, 4: 1-35.

Metropolitan Area Research Group [Eron, L.D., Huesmann, L.R., Spindler, A., Guerra, N.G., Henry, D., Tolan, P., and Van Acker, R.] (2002) 'A Cognitive/ Ecological Approach to Preventing Aggression in Urban Settings: Initial Outcomes for High Risk Children', Journal of Consulting and Clinical Psychology, 70 (1): 179-94.

Miczek, K.A., DeBold, J.F., Haney, M., Tidey, 3., Vivian, J., and Weerts, E.M. (1994) 'Alcohol, Drugs of Abuse, Aggression and Violence', in A.J. Reiss and J.A. Roth (ed.), National Research Council: Understanding and Preventing Violence (vol. 3). Social Influences. Washington, DC: National Academy Press. pp. 377-570.

Miczek, K.A., Mirsky, A.F., Carey, G., DeBold, J., and Raine, A. (1994) 'An Overview of Biological Influences on Violent Behavior', in National Research Council, Understanding and Preventing Violence (vol. 2). Washington, DC: National Academy Press. pp. 1-20.

Milavsky, JR., Kessler, R., Stipp, H., and Rubens, W.S. (1982) 'Television and Aggression: Results of a Panel Study', in D. Pearl, L. Bouthilet and J. Lazar (eds), Television and Behavior: Ten Years of Scientific Progress and Implications for the 80's (vol. 2). Technical Reviews. Washington, DC: Government Printing Office.

Miles, DR. and Carey, G. (1997) 'Genetic and Environmental Architecture of Aggression', Journal of Personality and Social Psychology, 72: 207-17.

Miller, I. and Norman, W. (1979) 'Learned Helplessness in Humans: A Review and Attribution Theory Model', Psychological Bulletin, 86: 93-118.

Miller, L.S. (1991) 'Mothers' and Children's Attitudes About Aggression'. Dissertation abstracts.

Mischel, W. and Shoda, Y. (1995) 'A Cognitive-Affective System Theory of Personality: Reconceptualizing Situations, Dispositions, Dynamics and Invariance in Personality Structure', Psychological Review, 102: 246-68.

Mischel, W. (1973) 'Toward a Cognitive Social Learning Reconceptualization of Personality', Psychological Review, 80: 252-83.

Mofiitt, T.E. (1990) 'Juvenile Delinquency and Attention Deficit Disorder: Boys' Developmental Trajectories from Age 3 to 15', Child Development, 61: 893-910.

Moffitt, T.E. and Lynam, DR. (1994) 'The Neuropsychology of Conduct Disorder and Delinquency: Implications for Understanding Antisocial Behavior', in 
D.C. Fowles, P. Sutker, and S.H. Goodman (eds), Progress in Experimental Personality and Psychopathology Research. New York: Springer-Verlag. pp. 233-62.

Moffitt, T.E., Gabrielli, W.F., Mednick, S.A., and Schulsinger, F. (1981) 'Socioeconomic Status, IQ and Delinquency', Journal of Abnormal Psychology, 90: 152-6.

Moise-Titus, J. (1999) 'The Role of Negative Emotions in the Media Violence-Aggression Relation'. Unpublished doctoral dissertation, University of Michigan, Ann Arbor, MI.

Murdoch, D., Pihl, R.O., and Ross, D. (1990) 'Alcohol and Crimes of Violence: Present Issues', International Journal of the Addictions, 25: 1065-8 1.

Nasby, H., Hayden, B., and DePaulo, B.M. (1979) 'Attributional Bias Among Aggressive Boys to Interpret Unambiguous Social Stimuli as Displays of Hostility', Journal of Abnormal Psychology, 89: 459-68.

Nisbett, R.E. (1993) 'Violence and U.S. Regional Culture', American Psychologist, 48: 441-9.

Nisbett, R.E. and Cohen, D. (1996) Culture of Honor: The Psychology of Violence in the South. Boulder, CO: Westview Press.

O'Donnell, C.R. (1995) 'Firearm Deaths Among Children and Youth', American Psychologist, 50: 771-6.

Olweus, D. (1979) 'Stability of Aggressive Reaction Patterns in Males: A Review', Psychological Bulletin, 86: 852-75.

Olweus, D. (1995) 'Bullying or Peer Abuse at School: Facts and Intervention', Current Directions in Psychological Science, 4: 196-200.

Oreland, L., Wiberg, A., Asberg, M., Traskman, L., Sjostrand, L., Thoren, P.L., Bertilsson, L., and Tybring, G. (1981) 'Platelet MAO Activity and Monoamine Metabolites in Cerebrospinal Fluid in Depressed and Suicidal Patients and in Health Control', Psychiatry Research, 4: 21-9.

Osofsky, J.D. (1995) 'The Effects of Exposure to Violence on Young Children', American Psychologist, 50: 782-8.

Pakaslahti, L. and Keltikangas-Jarvinen, L. (1996) 'Social Acceptance and the Relationship Between Aggressive Problem-Solving Strategies and Aggressive Behavior in 14-Year-Old Adolescents', European Journal of Personality, 10: 249-61.

Parker, RN. and Auerhahn, K. (1999) 'Drugs, Alcohol and Homicide', in M.D. Smith and M.A. Zahn (eds), Homicide: A Sourcebook of Social Research. Thousand Oaks, CA: Sage. pp. 176-91.

Patterson, G.R., Debaryshe, B.D., and Ramsey, E. (1989) 'A Developmental Perspective on Antisocial Behavior', American Psychologist, 44: 329-35.

Payne, K. (2002) 'On Losing It: Accessibility and Cognitive Control in Social Situations'. Paper presented at Society for Personality and Social Psychology meetings, Savannah, Georgia, February.

Pedersen, W.C., Gonzales, C., and Miller, N. (2000) 'The Moderating Effect of Trivial Triggering Provocation on
Displaced Aggression', Journal of Personality and Social Psychology, 78: 913-27.

Pennington, B.F. and Bennetto, L. (1993) 'Main Effects of Transactions in the Neuropsychology of Conduct Disorder.' Commentary on "The Neuropsychology of Conduct Disorder"; Development and Psychopathology, 5: 153-64.

Peterson, L., Gable, S., Doyle, C., and Ewugman, B. (1997) 'Beyond Parenting Skills: Battling Barriers and Building Bonds to Prevent Child Abuse and Neglect', Cognitive and Behavioral Practice, 4: 53-74.

Pfeffer, C.R., Zuckerman, S., Plutchik, R., and Mizruchi, MS. (1987) 'Assaultive Behavior in Normal Schoolchildren', Child Psychiatry and Human Development, 17: 166-76.

Poznanski, E. and Zrull, J.P. (1970) 'Childhood Depression: Clinical Characteristics of Overtly Depressed Children', Archives of General Psychiatry, 23: 8-15.

Prentice-Dunn, S. and Rogers, R. (1983) 'Deindividuation in Aggression', in R.G. Geen and E. Donnerstein (eds), Aggression: Theoretical and Empirical Reviews (vol. 2). New York: Academic Press. pp. 155-71.

Pulkkinen, L. (1996) 'Proactive and Reactive Aggression in Early Adolescence as Precursors to Anti- and Prosocial Behavior in Young Adults', Aggressive Behavior, 22: 241-57.

Raine, A. (1993) The Psychopathology of Crime: Criminal Behavior as A Clinical Disorder. San Diego, CA: Academic Press.

Raine, A., Brennen, PA., Farrington, D.P., and Mednick, S.A. (eds) (1997) Biosocial Bases of Violence. London: Plenum.

Raine, A., Venables, P.H., and Williams, M. (1990) 'Relationships Between CNS and ANS Measures of Arousal at Age 15 and Criminality at Age 24', Archives of General Psychiatry, 47: 1003-7.

Ramirez, J.M., Lagerspetz, K., Fraczek, A., Fujihara, T., Musazahedeh, Z., and Theron, W.H. (2001) 'Difference and Similarities in Moral Approval of Aggressive Acts: A Cross-National Study', Aggressive Behavior, 27 (3): 225-6.

Reinisch, J.M. (1981) 'Prenatal Exposure to Synthetic Progestins Increases Potential for Aggression in Humans', Science, 211: 1171-3.

Rice, M.E. (1997) 'Violent offender Research and Implications for the Criminal Justice System', American Psychologist, 52: 414-23.

Richard, BA. and Dodge, K.A. (1982) 'Social Maladjustment and Problem-Solving in School-Aged Children. Journal of Consulting and Clinical Psychology, 50: 226-33.

Rogeness, GA., Cepeda, C., Macedo, C.A., Fischer, C., and Harris, W.R. (1990) 'Differences in Heart Rate and Blood Pressure in Children with Conduct Disorder, Major Depression and Separation Anxiety', Psychiatry Research, 33: 199-206.

Rosenfeld, E., Huesmann, L.R., Eton, L.D., and TorneyPurta, J.V. (1982) 'Measuring Patterns of Fantasy Behavior in Children', Journal of Personality and Social Psychology, 42: 347-66. 
Rosenthal, R. (1986) 'The Social Consequences of Small Effects', Journal of Social Issues, 42: 141-54.

Rubin, K.H., Bream, L.A., and Rose-Krasnor, L. (1991) 'Social Problem Solving and Aggression in Childhood', in D.J. Pepler and K.H. Rubin (eds), The Development and Treatment of Childhood Aggression. Hillsdale, NJ: Erlbaum. pp. 219-48.

Rubin, K.H., Moller, L., and Emptage, A. (1987) 'The Preschool Behavior Questionnaire: A Useful Index of Behavior Problems in Elementary School-Age Children', Canadian Journal of Behavioral Science, 19: 86-100.

Russell, G.W. (1993) The Social Psychology of Sport. New York: Springer.

Rydin, E., Schalling, D., and Asberg, M. (1982) 'Rorschach Ratings $m$ Depressed and Suicidal Patients with Low Levels of 5-Hydroxyindoleacetic Acid in Cerebrospinal Fluid', Psychiatric Research, 7: 229-43.

Rys, G.S. and Bear, G.G. (1997) 'Relational Aggression and Peer Relations: Gender and Developmental Issues', Merrill-Palmer Quarterly, 43: 87-106.

Salvador, A., Simon, V., Suay, F., and Llorens, L. (1987) 'Testosterone and Cortisol Responses to Competitive Fighting in Human Males: A Pilot Study', Aggressive Behavior, 13: 9-13.

Satterfield, J.H., Hoppe, C.M., and Schell, A.M. (1982) A. Prospective Study of Delinquency in 110 Adolescent Boys with Attention Deficit Disorder and 88 Normal Adolescent Boys', American Journal of Psychiatry, 139: 795-8

Schaal, B., Tremblay, R.E., Soussignan, R., and Susman, E.J. (1995) 'Male Testosterone Linked to High Social Dominance but Low Physical Aggression in Early Adolescence'. Unpublished manuscript, University of Montreal.

Schneider, D.J. (1991) 'Social Cognition', Annual Review of Psychology, 42, 527-561.

Schneider, W. and Shiffrin, R.M. (1977) 'Controlled and Automatic Human Information Processing: I. Detection, Search and Attention', Psychological Review, 84: 1-66.

Sedikides, C. and Skowronski, J.J. (1990) 'Towards Reconciling Personality and Social Psychology: A Construct Accessibility Approach', Journal of Social Behavior and Personality, 5: 531-46.

Seligman, M.E.P. (1970) 'On the Generality of the Law of Learning', Psychological Review, 77: 406-18.

Shantz, C.U. and Shantz, D.W. (1985) 'Conflict Between Children: Social-Cognitive and Sociometric Correlates', New Directions for Child Development, 20: 3-21.

Shiffrin, R.M. and Schneider, W. (1977) 'Controlled and Automatic Human Information Processing: II. Perceptual Learning, Automatic Attending and General Theory', Psychological Review, 84: 127-90.

Shure, M.B. and Spivack, G. (1980) 'Interpersonal Problem-Solving as a Mediator of Behavioral Adjustment in Preschool and Kindergarten Children', Journal of Applied Developmental Psychology, 1:45-57.
Simon, L.M.J. (1998) 'Does Criminal offender Treatment Work?', Applied and Preventive Psychology, 7: 137-59.

Slaby, R.G. and Guerra, N.G. (1988) 'Cognitive Mediators of Aggression in Adolescent offenders: I. Assessment', Developmental Psychology, 24: 580-8.

Smith, S.L. and Donnerstein, E. (1998) 'Harmful Effects of Exposure to Media Violence: Learning of Aggression Emotional Desensitization, and Fear', in R.G. Geen and E. Donnerstein (eds), Human Aggression.' Theories, Research and Implications for Social Policy. New York: Academic Press. pp. 167-202.

Soubrie, P. (1986) 'Reconciling the Role of Central Serotoning Neurons in Humans and Animal Behavior', The Behavioral and Brain Sciences, 9: 319-64.

Souweidane, V. and Huesmann, L.R. (1999) 'The Influence of American Urban Culture on the Development of Normative Beliefs About Aggression in Middle-Eastern Immigrants', American Journal of Community Psychology, 27 (2): 239-54.

Staub, E. (1989) The Roots of Evil.' The Origins of Genocide and Other Group Violence. New York: Cambridge University Press.

Staub, E. (1998) 'Breaking the Cycle of Genocidal Violence: Healing and Reconciliation', in J. Harvey (ed.), Perspectives on Loss: A Sourcebook. Philadelphia: Taylor \& Francis, pp. 23-38.

Steele, C.M. and Josephs, R.A. (1990) 'Alcohol Myopia: Its Prized and Dangerous Effects', American Psychologist, 45: 921-33.

Steinberg, M.D. and Dodge, K.A. (1983) 'Attributional Bias in Aggressive Boys and Girls', Journal of Social and Clinical Psychology, 1: 312-21.

Stenberg, C.R. and Campos, J.J. (1990) 'The Development of Anger and Expressions in Infancy', in N. Stein, B. Leventhal, and T. Trabasso (eds), Psychological and Biological Approaches to Emotion. Hillsdale, NJ: Erlbaum.

Stenberg, C., Campos, J. and Emde, R. (1983) 'The Facial Expression of Anger in Seven-Month-Old Infants', Child Development, 54: 178-84.

Stoff, D.M., Pollack, L., Vetiell, B., Behar, D., and Bridger, W.H. (1987) 'Reduction of [3H]-Imipramine Binding Sites on Platelets of Conduct-Disordered Children', Neuropsychopharmacology, 1: 55-62.

Straus, M.A. (1997) 'Physical Assaults by Women Partners: A Major Social Problem', in MR. Walsh (ed.), Women. Men and Gender: Ongoing Debates. New Haven, CT: Yale University Press. pp. 210-21.

Straus, MA. (2000) Beating the Devil Out of Them: Corporal Punishment by American Families and Its Effects on Children, 2nd edn. Somerset, NJ: Transaction Publishers.

Surgeon General (2001) Youth Violence: A Report of the Surgeon General. Rockville, MD: US Department of Health and Human Services.

Tate, D.C., Reppucci, ND., and Mulvey, E.P. (1995) 'Violent Juvenile Delinquents: Treatment Effectiveness and Implications for Future Action', American Psychologist, 50: 777-81. 
Taylor, AR and Gabriel, SW. (1989) 'Cooperative Versus Competitive Game-Playing Strategies of Peer Accepted and Peer Rejected Children in a Goal Conflict Situation'. Paper presented at the biennial meeting of the Society for Research in Child Development, Kansas City, MO.

Taylor, S.P. and Leonard, K.E. (1983) 'Alcohol and Human Physical Aggression', in R.G. Green and E. Donnerstein (eds), Aggression: Theoretical and Empirical Reviews (vol. 2). New York: Academic Press. pp. 77-101.

Tellegen, A., Lykken, D.T., Bouchard, Jr., T.J., Wilcox, K.J., Segal, N.L., and Rich, S. (1988) 'Personality Similarity in Twins Reared Apart and Together', Journal of Personality and Social Psychology, 54: 1031-9.

Thomas, M.H., Horton, R.W., Lippincott, E.C., and Drabman, R. S. (1977) 'Desensitization to Portrayals of Real Life Aggression as a Function of Television Violence', Journal of Personality and Social Psychology, 35: 450-8.

Todorov, A. and Bargh, J.A. (2002) 'Automatic Sources of Aggression', Aggression and Violent Behavior, 7: 53-68.

Tremblay, R.E. (2000) 'The Development of Aggressive Behavior During Childhood: What Have We Learned in the Past Century?', International Journal of Behavioral Development, 24: 129-41.

Tremblay, R.E., Boulerice, B., Harden, P.W., Mcduff, P., Perusse, D., PihI, R.O., and Zoccolillo, M. (1996) 'Do Children in Canada Become More Aggressive as They Approach Adolescence?', in Human Resources Development Canada (ed.), Growing up in Canada. National Longitudinal Survey of Children and Youth. Ottawa: Statistics Canada. pp. 127-37.

US Department of Justice (1992) A National Crime Victimization Survey Report. December 1992. Justice Statistics Clearinghouse, National Criminal Justice Reference Service. Box 6000, Rockville, MD, 20850.

US Department of Justice Bureau of Justice Statistics (2001) Homicide Trends in the United States. http//:www.ojp.usdoj.gov/bjs/homicide/homtrnd.htm.

Ulrich, R.E. (1966) 'Pain as a Cause of Aggression', American Zoologist, 6: 643-62.

Verlinden, S., Herden, M. and Thomas, J. (2000) 'Risk Factors in School Shootings', Clinical Psychology Review, 20: 3-56.

Viemero, V. and Paajanen, 5. (1992) 'The Role of Fantasies and Dreams in the TV Viewing-Aggression Relationship', Aggressive Behavior, 18 (2): 109-16.

Virkkunen, M. (1985) 'Urinary Free Cortisol Secretion in Habitually Violent Offenders', Acta Psychiatrica Scandinavica, 72: 40-4.

Virkkunen, M., De Jong, J., Bartko, 3., Goodwin, F.K., and Linnolia, M. (1989a) 'Relationship of Psychobiological Variables to Recidivism in Violent Offenders and
Impulsive Fire Setters', Archives of General Psychiatry, 46: 600-3.

Virkkunen, M., De Jong, 3., Bartko, J., and Linnolia, M. (1989b) 'Psychobiological Concomitants of History of Suicide Attempts Among Violent Offenders and Impulsive Fire Setters', Archives of General Psychiatry, 46: 604-6.

Virkkunen, M. and Narvanen, S. (1987) 'Plasma Insulin, Tryptophan and Serotonin Levels During the Glucose Tolerance Test Among Habitually Violent and Impulsive offenders', Neuropsychobiology, 17: 19-23.

Waas, G.A. (1988) 'Social Attributional Biases of Peer-Rejected and Aggressive Children', Child Development, 59: 969-92.

Wadsworth, M.E.J. (1976) 'Delinquency, Pulse Rate and Early Emotional Deprivation', British Journal of Criminology, 16: 245-56.

West, D.J. and Farrington, D.P. (1973) Who Becomes Delinquent? Second Report of the Cambridge Study in Delinquent Development. London: Heinemann.

White, J.W. (in press) 'Gendered Aggression Across the Lifespan', Encyclopedia of Gender.

Widom, C.S. (1989) 'Does Violence Beget Violence? A Critical Examination of the Literature', Psychological Bulletin, 106 (1): 3-28.

Wiehe, V.R. (1998) Understanding Family Violence. Thousand Oaks, CA: Sage.

Wilson, J.Q. and Herrnstein, R.J. (1985) Crime and Human Nature. New York: Simon \& Schuster.

Winter, L. and Uleman, J.S. (1984) 'When Are Social Judgements Made? Evidence for the Spontaneousness of Trait Inference', Journal of Personality and Social Psychology, 4: 904-17.

Zelli, A. and Huesmann, L.R. (1993) 'Accuracy of Social Information Processing by Those Who Are Aggressive: The Role of Beliefs About a Hostile World'. Prevention Research Center, University of Illinois at Chicago.

Zelli, A., Huesmann, L.R., and Cervone, D.P. (1995) 'Social Inferences in Aggressive Individuals: Evidence for Automatic Processing in the Expression of Hostile Biases', Aggressive Behavior, 21: 405-18.

Zigler, E., Taussig, C., and Black, K. (1992) 'Early Childhood Intervention: A Promising Preventative for Juvenile Delinquency', American Psychologist, 47:997-1006.

Zillmann, D. (1979) Hostility and Aggression. Hillsdale, NJ: Erlbaum.

Zillmann, D. (1983) 'Arousal and Aggression', in R. Geen and E. Donnerstein (eds), Aggression: Theoretical and Empirical Reviews (vol. 1). New York: Academic Press. pp. 75-102.

Zubriggen, E.I. (2000) 'Social Motives and Cognitive Power-Sex Associations: Predictors of Aggressive Sexual Behavior', Journal of Personality and Social Psychology, 78: 559-81. 